\title{
Geochemistry and geochronology of the mafic dikes in the Taipusi area, northern margin of North China Craton: Implications for Silurian tectonic evolution of the Central Asian Orogen
}

\author{
Jing-Hua Wu ${ }^{1}$, Huan Li ${ }^{1, *}$, XiaO-Shuang Xi ${ }^{2}$, Hua Kong ${ }^{2}$, Qian-Hong Wu ${ }^{2}$, \\ Neng-Li Peng ${ }^{3}$, Xi-Ming Wu ${ }^{4}$, Jing-Ya CAO ${ }^{2}$ and Jillian Aira S Gabo-Ratio ${ }^{5}$ \\ ${ }^{1}$ Department of Resources Science and Engineering, China University of Geosciences, No. 388 Lumo Road, \\ Wuhan 430 074, People's Republic of China. \\ ${ }^{2}$ School of Geosciences and Info-Physics, Central South University, Changsha 410 083, People's Republic \\ of China. \\ ${ }^{3}$ Hunan Institute of Geological Survey, Changsha 410 016, People's Republic of China. \\ ${ }^{4}$ Guangxi Land and Resources Planning Institute, Nanning 530 022, People's Republic of China. \\ ${ }^{5}$ National Institute of Geological Sciences, University of the Philippines, Diliman, 1101 Quezon City, \\ Philippines. \\ *Corresponding author.e-mail: lihuan@cug.edu.cn
}

MS received 18 October 2016; revised 10 February 2017; accepted 10 February 2017; published online 6 July 2017

The Taipusi area in the Bainaimiao Arc Belt is located in the northern margin of the North China Craton, at the southern margin of the middle Central Asian Orogenic Belt. It is characterized by large exposures of mafic dikes. In this contribution, we present first-hand whole-rock major and trace elements, zircon $\mathrm{U}-\mathrm{Pb}$ geochronology and in situ trace element geochemistry data for these mafic rocks, which reveal their petrogenesis and tectonic evolution. These mafic dikes display varied compositions of $\mathrm{SiO}_{2}$ (49.42-54.29\%), $\mathrm{TiO}_{2}$ (0.63-1.08\%), $\mathrm{Al}_{2} \mathrm{O}_{3}$ (13.94-17.60\%), $\mathrm{MgO}$ (4.66-10.51\%), $\mathrm{Fe}_{2} \mathrm{O}_{3}$ (1.59-3.07\%), $\mathrm{FeO}$ (4.60-6.90\%), $\mathrm{CaO}$ (4.57-8.91\%), $\mathrm{Na}_{2} \mathrm{O}$ (1.61-4.26\%), $\mathrm{K}_{2} \mathrm{O}(0.92-2.54 \%)$ and $\mathrm{P}_{2} \mathrm{O}_{5}(0.11-0.29 \%)$. They are mainly of high-K calc-alkaline series with indistinct Eu anomalies, enriched in large ion lithophile elements (e.g., $\mathrm{Rb}, \mathrm{Ba}, \mathrm{K}$ and $\mathrm{Sr}$ ) but depleted in high field strength elements (e.g., Nb, $\mathrm{P}$ and $\mathrm{Ti}$ ). These suggest that the crystallizing magma was derived from enriched mantle altered by metasomatic fluids in a subduction setting with imprints of active continental margin features. The high concentrations of $\mathrm{Hf}, \mathrm{U}, \mathrm{Th}, \mathrm{Pb}$ and $\mathrm{Y}$, pronounced positive Ce but slightly negative $\mathrm{Eu}$ anomalies in zircons indicating that the magma underwent a fractional crystallization and crustal contamination process, with medium to high $f_{2}$. Zircon LA-ICP-MS U-Pb dating yielded concordant ages of 437-442 Ma for these mafic dikes, which is consistent with the early Paleozoic volcanic arc magmatic activity in the Bainaimiao area. Hence, we conclude that the Bainaimiao Arc Belt is a continental arc formed by the southward subduction of the Paleo-Asian ocean during early Paleozoic.

Keywords. Mafic dikes; zircon U-Pb dating; tectonic setting; Bainaimiao Arc Belt; Central Asian Orogenic Belt. 


\section{Introduction}

As one of the largest Phanerozoic orogenic accretionary belt in the world, the Central Asian Orogenic Belt (CAOB) is of great interest due to its long-term evolutionary history and complex tectonic magmatism (Windley et al. 2006). The Xing-Meng Orogenic Belt (XMOB), located at the eastern part of the CAOB within China, is about $2000 \mathrm{~km}$ long and $500 \mathrm{~km}$ wide and borders the Siberian Craton to the north and North China Craton to the south (figure 1a). Accompanied by widespread occurrence of various tectonic components, such as Precambrian microcontinents, Paleozoic island arcs, ophiolites, accretionary wedges, oceanic plateaus and successions of volcanic rocks, the XMOB has undergone multi-stage complex tectonic evolution, such as oceanic subduction, crustal accretion, multi-block collision and post-orogenic extension due to consumption of the Paleo-Asian Ocean (PAO) between the Paleozoic and the early Mesozoic (Sengör et al. 1993; Chen et al. 2000; Xiao et al. 2003). The XMOB tectonically consists of Northern Orogenic Belt (NOB), Solonker Suture and Southern Orogenic Belt (SOB) from the north to the south with several large linear faults as dividing lines (figure 1b; Khain et al. 2003; Jahn 2004; Xiao et al. 2004, 2009).

At the southern part of SOB, the $\mathrm{E}-\mathrm{W}$ trending Bainaimiao Arc Belt (BAB) is located between Xilamulun fault and Chifeng-Baiyanobo fault (Jian et al. 2008). It is mainly composed of calc-alkaline tholeiitic basalts, felsic lavas, alkaline basalts, agglomerates, volcanic breccias, tuffs, granodiorites and granites (Zhao and Zhai 2013). The formation of the BAB is attributed mainly to the southward subduction of the PAO during the early Paleozoic, which led to the large-scale products of volcanic activity between Bainaimiao and Chifeng cities (Stampfli and Borel 2002). The formation, distribution and evolution of magmatism are closely related to the tectonic evolution of the area, and thus play a key role in identifying the tectonic environment. However, the space-time framework and tectonic setting of the early Paleozoic magmatism in the $\mathrm{BAB}$ have not yet reached unified understanding. The BAB has been identified as an island arc by many researchers (e.g., Jong et al. 2006) while others consider it as an Andean-type continental arc within the northern margin of North China Craton (e.g., Xiao et al. 2003); some researchers still suggest that there used to be a broad ocean that separated the northern NCC from BAB during the Cambrian-Ordovician period, which resulted in the formation of BAB (e.g., Zhang et al. 2014). In addition, previous studies in the area paid more attention to the geochemistry and geochronology of granite rocks in the western part of BAB. For example, U-Pb concordant ages of $\sim 446$ and $\sim 443$ Ma have been determined in Damaoqi and Bainaimiao, respectively (Zhang and Jian 2008; Feng et al. 2014). Due to the diverse granitic types and uncertain nature of magmatic source areas, the (a)

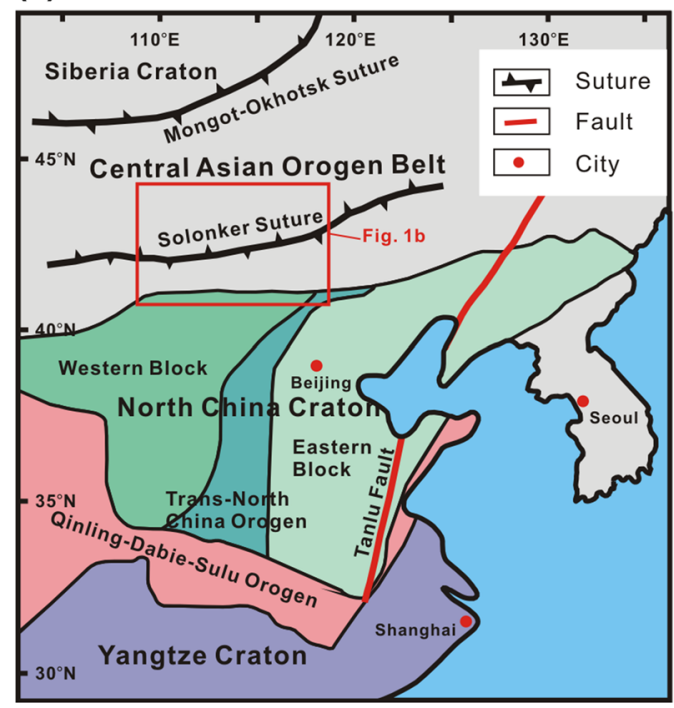

(b)

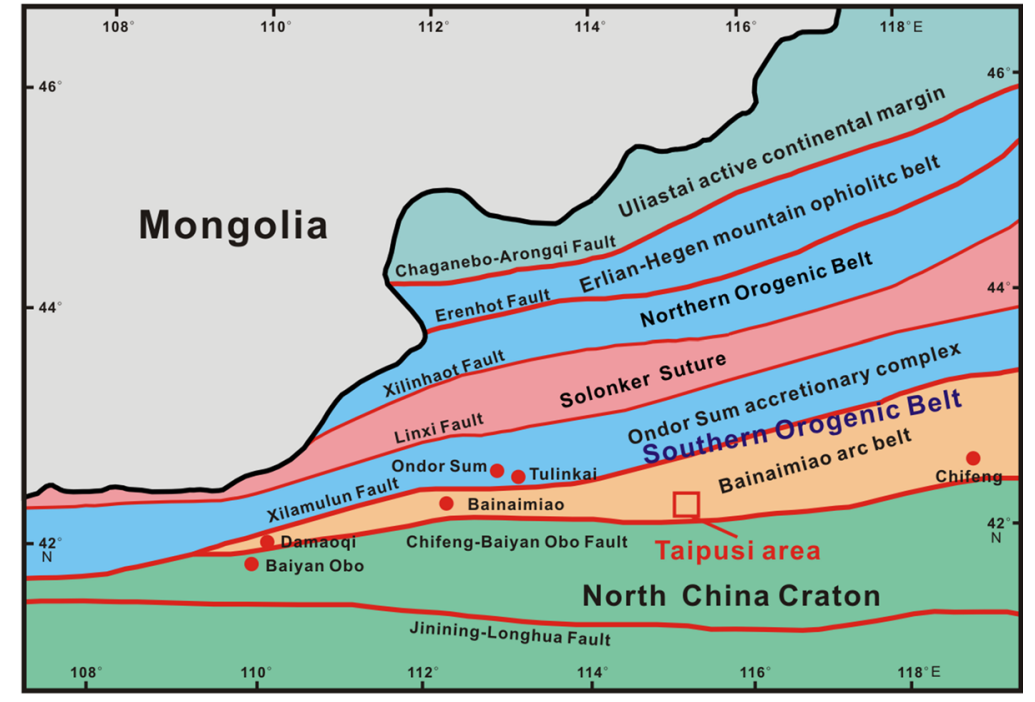

Figure 1. (a) Tectonic map of North China Craton and its adjacent areas (after Zhao et al. 2001) and (b) regional geological map of the Central Asian Orogenic Belt (after Xiao et al. 2003). 
tectonic background of the Bainaimiao area is still controversial.

This study hopes to provide further constraints on this disputed tectonic environment from new approaches using local magmatic rocks. The Taipusi area is situated in the south of Xinlingol League, inner Mongolia autonomous region of North China, within the southmost middle segment of BAB. There have been limited geochemical and geochronological studies of mafic dikes in the middle part of Bainaimiao Arc Belt, which may host abundant information and provide constraints on the tectonic evolution of BAB.

Mafic rocks usually originate from the mantle and are closely related to mantle-derived rocks, which are associated with global tectonics (such as plate subduction and deep mantle processes). Thus, mafic rocks are of great significance in investigating source properties and analysing tectonic setting and deep kinetics of the lithosphere ( $\mathrm{Li}$ et al. 2016). Furthermore, the study of the nature, source region, evolution, origin and dynamic background of mafic magma is the key to obtain information about related internal processes for further revealing magmatic generation and activity related to deep kinetic mechanisms. Based on field geological observation, the occurrence of the Taipusi area mafic dikes may be linked to the tectonic evolution of BAB.

Hence, based on comprehensive analysis of zircon $\mathrm{U}-\mathrm{Pb}$, geochronology and whole-rock, and zircon geochemistry, this study aims to reveal the origin and evolution of mafic magma in Taipusi area and provide new insights into the early Paleozoic tectonic evolution of BAB.

\section{Regional tectonic evolution and geology}

The northern margin of the NCC records a long history of crustal growth, tectonic evolution and stabilization from Archean to Paleoproterozoic (Santosh 2010; Zhao et al. 2010). During the Paleozoic, the northern margin of NCC was once strongly influenced by southward subduction of the Paleo-Asian ocean as indicated by surface tectonics and magmatism (Cope et al. 2005; Zhang et al. 2010). The consumption of PAO eventually led to the collision of North China Craton with the Siberia Craton, with Solonker Suture as the evidence for the termination of this collisionaccretion process (Xiao et al. 2003). However, the tectonic model and time constraint for this subduction is still controversial. Based on detailed investigation of subduction- and collision-related magmas and forearc sediments in Solonker Suture zone, Chen et al. (2009) suggested that the opposing subduction of the PAO started from $530 \mathrm{Ma}$ and ended between 296 and 234 Ma. In contrast, Jian et al. (2010) considered that the tectonic evolution for central southern CAOB can be classified into two independent subduction-collision processes that occurred during the early Paleozoic and also during the late Carboniferous-late Permian. Recently, a new model suggested that there used to be a southern subduction-collision system between North China Craton and Hunshandake Block during 500-440 $\mathrm{Ma}$ as well as a northern subduction-collision system between South Mongolia Microcontinent and Hunshandake Block during 500-380 Ma, resulting in the formation of SOB and NOB in 410 and 380 Ma, respectively (Xu et al. 2013). Until recent times, the closure of the Paleo-Asian ocean is postulated to have occurred between Permian and Triassic (Chen et al. 2000; Jian et al. 2008; Xiao et al. 2009). Although the existence of a Paleozoic subduction is an accepted fact, the formation, distribution and evolution of mafic rocks still require further investigation to provide more constraints in establishing the ancient tectonic environment of BAB.

The tectonic framework of XMOB and adjacent areas include several tectonic units from north to south, such as the Ulilastai Continental Margin, Erlian-Hegen Mountain Ophiolitic Belt, Northern Orogenic Belt (NOB), Solonker Suture and Southern Orogenic Belt (SOB) (figure 1b, Jian et al. 2008). The Erlian-Hegen Mountain ophiolitic complex is on the south of the Wuliang Yasi-Taiyuan continental margin, which consists of volcanic sedimentary strata, granite, blue schist, and a large number of ophiolites (Miao et al. 2008). The NOB is composed of Xilinhaot metamorphic complexes, Erdaojing complex, and two types of magmatic rocks associated with island arcs and collision features in Baolilao area ( $\mathrm{Xu}$ et al. 2013). Representing the termination of the CAOB evolution in inner Mongolia, the Solonker Suture is marked by ophiolite exposures in the Sonlonker, Xiamulun and Linxi areas and separates XMOB into two orogenic belts (Jian et al. 2008). The area is bounded by Linxi fault to the north and Xilamulun fault to the south (Li et al. 2012a).

The main tectonic units of the SOB include the Bainaimiao Arc Belt (BAB) and the Ondor 


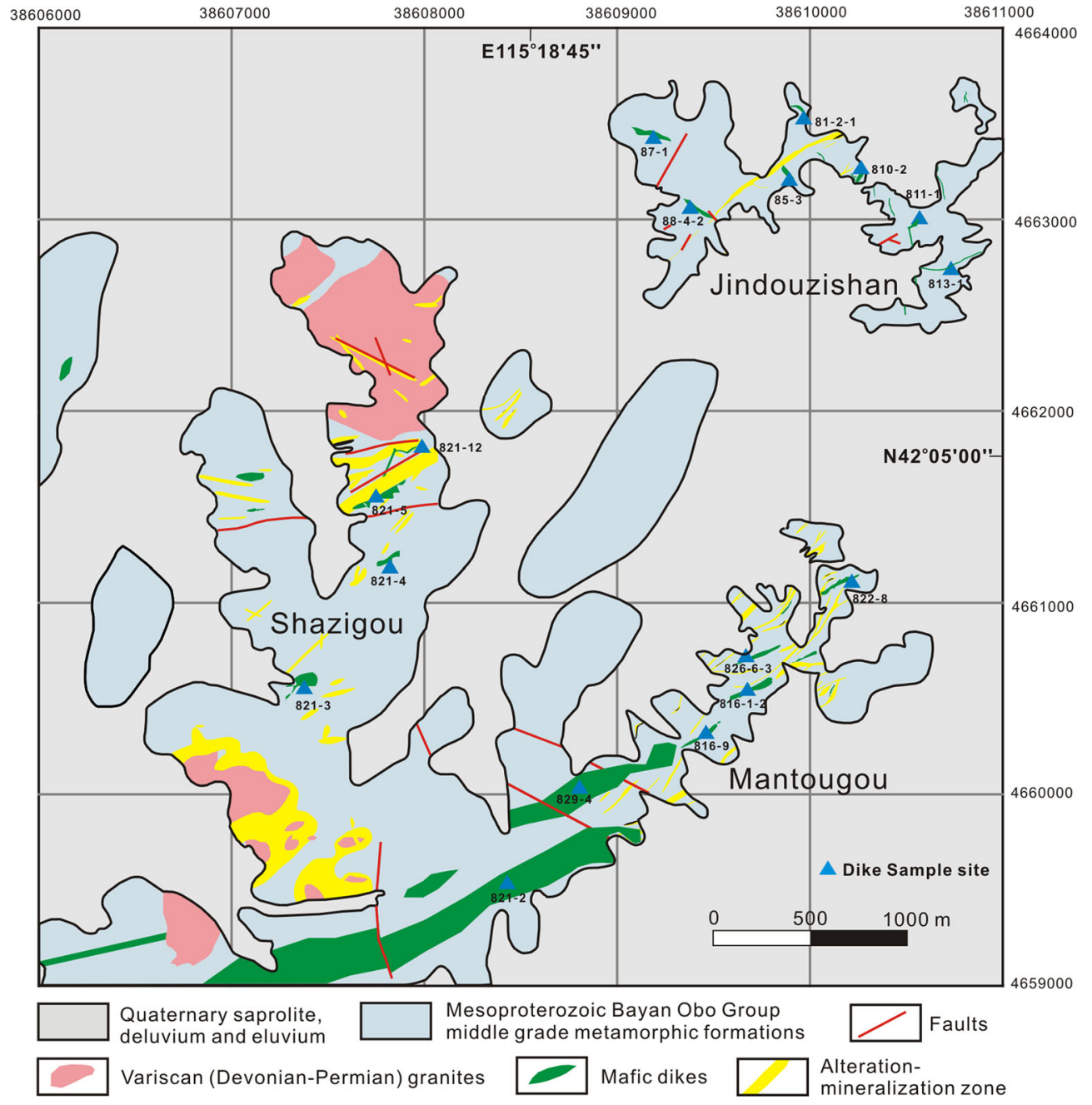

Figure 2. Simplified geological map of the Taipusi area (after Li et al. 2017).

Sum subduction-accretionary complex. The Ondor Sum complex is located to the north of the $\mathrm{BAB}$ and can be further subdivided into three units: underformed ophiolite belt, island arc complex, and mylonitized UHP subduction complex. The BAB is characterized by an assemblage of calc-alkaline tholeiitic basalts, felsic lavas, alkaline basalts, agglomerates, volcanic breccias, tuffs, granodiorites and granites (Xiao et al. 2003; Li et al. 2015). Four major geological units can be differentiated in the Bainaimiao area, namely a greenschist-facies volcano-sedimentary sequence, a low-P/T metamorphic complex, a mid-late Silurian flysch sequence and a late Silurian molasse (Zhang et al. 2013).

The exposed strata in the Taipusi area mainly belongs to the Mesoproterozoic Bayan Obo Group, with large exposures of Quaternary alluvium and limited exposures of Variscan granitic rocks (Devonian-Permian) (figure 2). The Bayan Obo
Group structures trend NE-SW and consist of medium grade (partial to high grade) metamorphic formations. The photolytes are sedimentary clastic rocks, carbonate rocks and intermediate volcanic rocks. Divided into several lithologic sections, the Bayan Obo Group of the Taipusi area consists of garnet two-mica quartz schist, biotite quartz schist, marble, argillaceous slate, metamorphic feldspathic quartz sandstone, plagioclase amphibole schist, and banded migmatite. The Variscan granitic rocks are mainly medium-fine grained biotite-plagioclase granites and fine grained biotite adamellites, with intense silicification around the intrusive bodies. In addition, Permian-Triassic Mo polymetallic mineralization was formed in this area, with no obvious relationship with the outcropped magmatic rocks (Li et al. 2017).

The Taipusi area is characterized by widely distributed mafic dikes with different scales and occurrences (figure 2). They intruded into the Bayan 
Obo Group along secondary fractures. These dikes mainly consist of gabbro, diabase and lamprophyre (figure $3 \mathrm{a}-\mathrm{b}$ ). The diabase and gabbro are mainly distributed in the southern and northeastern portions. The diabase is greyish-green in colour, has a massive structure and an ophitic texture with plagioclase $(50 \%)$, pyroxene $(30 \%)$ and hornblende $(15 \%)$ as major minerals (figure 4a). The lamprophyre is dominantly located in the northern part of the ore field and has similar mineral composition exhibiting a porphyritic texture (figure $4 b$ ).

\section{Sampling and analytical techniques}

Different types of fresh mafic rocks were collected in the outcrops and exploratory trenches in the Taipusi area. Sampling locations of the representative samples are shown in figure 2 .
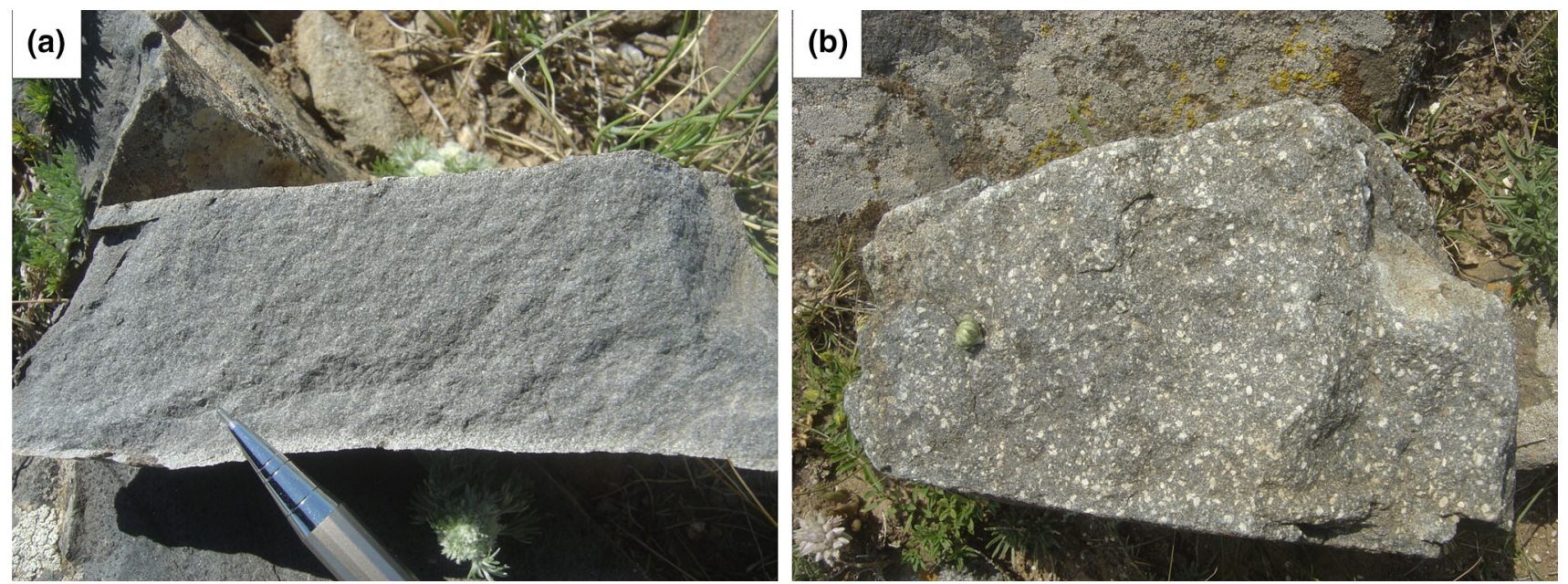

Figure 3. Field occurrences of diverse magmatic dikes in the Taipusi area (a) Diabase and (b) Gabbro.
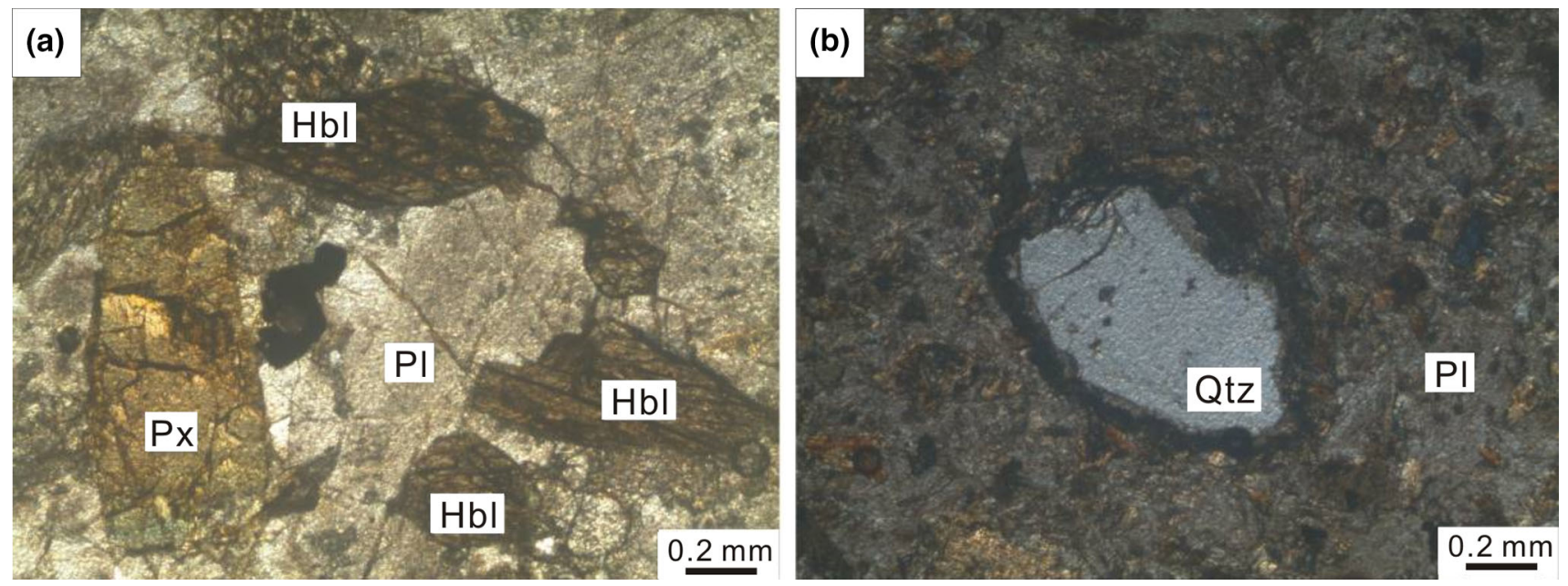

Figure 4. Micrograph images of the diverse magmatic dikes in the Taipusi area (a) Gabbro and (b) Lamprophyre. Px: pyroxene; Pl: plagioclase; Hbl: hornblende; Qtz: quartz. 
picking under binocular microscope and mounted in epoxy resin and polished down to expose the grain center. Cathodoluminescence (CL) imaging was carried out at Northwest University (China), using a scanning electron microscope equipped with an energy dispersive spectroscopy system and a CL3+ detector under an operating condition at $15 \mathrm{kV}$ and $20 \mathrm{nA}$. Typical CL images were obtained to identify internal structures and choose potential target sites for $\mathrm{U}-\mathrm{Pb}$ and trace element analyses.

In-situ zircon trace element and $\mathrm{U}-\mathrm{Pb}$ isotope analyses were performed at the State Key Laboratory of Continental Dynamics, Northwest University, China. An Agilent 7500a ICP-MS, equipped with a pulsed $193 \mathrm{~nm}$ ArF Excimer (Compex102) with laser power of $70 \mathrm{mj}$ pulse energy at a repetition rate of $10 \mathrm{HZ}$, was used for ablation. The laser ablation beam diameter was $30 \mu \mathrm{m}$ and the ablation depth was 20-40 $\mu \mathrm{m}$. Helium was used as carrier gas to provide efficient aerosol transport to the ICP and minimize aerosol deposition. To correct laser induced fractionation, the SSB (Sample Standard Bracket) method was performed. Zircon 91,500 was used as an external standard to normalize isotopic fractionation during isotope analysis, and it was analysed twice for every 5 analyses. Meanwhile, NIST610 glass, which was analysed once every 10 analyses, was used as an external standard. Detailed descriptions of analytical procedure and instrumentation are given by Yuan et al. (2008). Off-line selection and integration of background and analytical signals, time-drift correction and quantitative calibration for $\mathrm{U}-\mathrm{Pb}$ dating were performed using in-house software ICPMSDataCal (Liu et al. 2010), and the ${ }^{204} \mathrm{~Pb}$-based method was applied for common $\mathrm{Pb}$ correction (Andersen 2002). The ISOPLOT (version 4.15) program was employed for zircon concordant diagram plotting.

Zircon trace element concentration results were simultaneously obtained during zircon $\mathrm{U}-\mathrm{Pb}$ dating. Combined with external standard NIST610, ${ }^{91} \mathrm{Zr}$ was used as an internal standard to correct trace element concentrations of the unknowns. A detailed calibration procedure for each element was presented in Liu et al. (2010). The preferred values of element concentrations for the standard sample NIST610 glass are from the GeoReM database (http://georem.mpch-mainz.gwdg.de/). The average analytical error ranges from $\sim 10 \%$ for light rare earth elements (LREE) to $\sim 5 \%$ for other trace elements.

\section{Results}

\subsection{Major and trace elements of rocks}

The major and trace element concentrations of 18 mafic rock samples from the Taipusi area are shown in table 1 . The mafic rocks have varied chemical compositions in whole-rock geochemistry, with contents of $\mathrm{SiO}_{2}=49.42-54.29 \%, \mathrm{TiO}_{2}=0.63$ $1.08 \%, \mathrm{Al}_{2} \mathrm{O}_{3}=13.94-17.60 \%, \mathrm{MgO}=4.66-10.51 \%$, $\mathrm{Fe}_{2} \mathrm{O}_{3}=1.59-3.07 \%, \mathrm{FeO}=4.60-6.90 \%, \mathrm{CaO}=4.57-$ $8.91 \%, \mathrm{Na}_{2} \mathrm{O}=1.61-4.26 \%, \mathrm{~K}_{2} \mathrm{O}=0.92-2.54 \%$, and $\mathrm{P}_{2} \mathrm{O}_{5}=0.11-0.29 \%$. Total alkali content $\left(\mathrm{Na}_{2} \mathrm{O}+\right.$ $\mathrm{K}_{2} \mathrm{O}$ ) was $2.53-6.01 \%$, with an average value of $4.98 \%$. A/CNK values range from 0.71-0.95, with an average value of 0.79 . All of these imply a metaluminous signature for the mafic rocks. After the removal of LOI and recalculation of total majorelement oxides into $100 \%$, immobile elements (i.e., $\mathrm{Ti}, \mathrm{Zr}, \mathrm{Y}, \mathrm{Nb}$ ) are used to determine the rock types to eliminate the influence of the mobile alkaline elements. In the $\mathrm{Zr} / \mathrm{TiO}_{2}-\mathrm{Nb} / \mathrm{Y}$ diagram, samples are plotted as andesite or basalt (figure 5a). Furthermore, the samples mostly plot in the calc-alkaline series field in the AFM diagram (figure 5b), and high-K calc-alkaline series and calc-alkaline series fields in the $\mathrm{K}_{2} \mathrm{O}-\mathrm{SiO}_{2}$ diagram (figure 5c).

The total rare earth element ( $\mathrm{REE}$ ) compositions of these mafic rocks range from 68.11 to $128.95 \mathrm{ppm}$, averaging at $91.95 \mathrm{ppm}$ (table 1). The samples are characterized by the pronounced differentiation of LREE and HREE and the enrichment of LREE, with LREE/HREE and $(\mathrm{La} / \mathrm{Yb})_{\mathrm{N}}$ values ranging 4.97-8.96 and 4.58-9.88, respectively. REE patterns among different samples are similar to each other, with inclined lines for LREE but flat curves for HREE (figure 6a). The Eu and Ce negative anomalies are relatively weak, with average $\mathrm{Eu} / \mathrm{Eu}^{*}$ and $\mathrm{Ce} / \mathrm{Ce}^{*}$ values of 0.94 and 0.91 , respectively.

On primitive mantle-normalized multi-element diagrams (figure $6 \mathrm{~b}$ ), these mafic rock samples show enrichment in large ion lithophile elements (LILE) (e.g., Rb, Ba, K and Sr) and depletion in high field strength elements (HFSE) (e.g., Nb, P and $\mathrm{Ti}$ ).

\section{$4.2 \mathrm{U}-\mathrm{Pb}$ geochronology}

The zircon CL images of sample 821-12 and 8261 are present in figure 7 . The typical oscillatory zoning of these zircons indicate that they are 
Table 1. Major and trace element compositions and related calculating parameters for the mafic dikes from the Taipusi area.

\begin{tabular}{|c|c|c|c|c|c|c|c|c|c|}
\hline Sample no. & $816-9$ & $821-1$ & $826-6-3$ & $821-5$ & $821-3$ & $829-4$ & 821-12 & $821-2$ & $822-8$ \\
\hline $\mathrm{SiO}_{2}(\%)$ & 53.18 & 53.82 & 50.18 & 51.28 & 50.05 & 54.21 & 50.85 & 52.60 & 54.29 \\
\hline $\mathrm{TiO}_{2}$ & 0.75 & 0.96 & 0.87 & 0.98 & 1.07 & 0.78 & 1.00 & 0.74 & 0.78 \\
\hline $\mathrm{Al}_{2} \mathrm{O}_{3}$ & 14.6 & 16.9 & 14.5 & 16.0 & 16.0 & 15.6 & 15.4 & 15.5 & 14.7 \\
\hline $\mathrm{Fe}_{2} \mathrm{O}_{3}$ & 1.59 & 2.02 & 2.18 & 2.36 & 3.26 & 1.83 & 2.21 & 2.05 & 1.77 \\
\hline $\mathrm{FeO}$ & 6.00 & 5.20 & 6.90 & 5.90 & 5.55 & 5.75 & 6.55 & 5.70 & 5.45 \\
\hline $\mathrm{MnO}$ & 0.14 & 0.11 & 0.16 & 0.15 & 0.11 & 0.13 & 0.15 & 0.13 & 0.13 \\
\hline $\mathrm{MgO}$ & 8.65 & 6.14 & 10.51 & 6.76 & 8.12 & 7.11 & 7.51 & 7.51 & 8.30 \\
\hline $\mathrm{CaO}$ & 6.28 & 5.97 & 7.93 & 7.95 & 7.71 & 7.47 & 6.64 & 8.58 & 6.37 \\
\hline $\mathrm{Na}_{2} \mathrm{O}$ & 2.87 & 3.23 & 1.82 & 3.11 & 3.58 & 2.93 & 3.67 & 2.72 & 3.22 \\
\hline $\mathrm{K}_{2} \mathrm{O}$ & 2.28 & 2.54 & 2.17 & 2.14 & 1.66 & 1.25 & 2.30 & 1.46 & 2.00 \\
\hline $\mathrm{P}_{2} \mathrm{O}_{5}$ & 0.12 & 0.18 & 0.13 & 0.27 & 0.13 & 0.11 & 0.28 & 0.15 & 0.14 \\
\hline LOI & 2.54 & 2.06 & 1.81 & 2.14 & 1.91 & 1.96 & 2.47 & 2.00 & 1.88 \\
\hline TOTAL & 99.03 & 99.15 & 99.11 & 99.06 & 99.15 & 99.13 & 98.98 & 99.15 & 99.03 \\
\hline $\mathrm{Na}_{2} \mathrm{O}+\mathrm{K}_{2} \mathrm{O}$ & 5.15 & 5.77 & 3.99 & 5.25 & 5.24 & 4.18 & 5.97 & 4.18 & 5.22 \\
\hline $\mathrm{A} / \mathrm{NK}$ & 2.03 & 2.10 & 2.70 & 2.16 & 2.08 & 2.53 & 1.80 & 2.56 & 1.97 \\
\hline $\mathrm{A} / \mathrm{CNK}$ & 0.79 & 0.89 & 0.73 & 0.73 & 0.74 & 0.79 & 0.75 & 0.72 & 0.77 \\
\hline $\mathrm{Mg}^{\#}$ & 67 & 61 & 68 & 60 & 63 & 63 & 61 & 64 & 68 \\
\hline $\mathrm{FeO}_{\text {total }}$ & 7.43 & 7.02 & 8.86 & 8.02 & 8.48 & 7.40 & 8.54 & 7.54 & 7.04 \\
\hline La (ppm) & 17.2 & 20.2 & 13.2 & 15.0 & 12.5 & 12.3 & 17.3 & 12.5 & 16.7 \\
\hline $\mathrm{Ce}$ & 33.9 & 43.1 & 27.5 & 34.4 & 26.2 & 24.5 & 36.8 & 25.6 & 33.1 \\
\hline $\operatorname{Pr}$ & 4.51 & 5.81 & 3.74 & 4.68 & 3.60 & 3.42 & 4.96 & 3.45 & 4.48 \\
\hline $\mathrm{Nd}$ & 18.1 & 23.7 & 15.9 & 19.9 & 15.5 & 14.1 & 20.9 & 14.3 & 18.4 \\
\hline $\mathrm{Sm}$ & 3.86 & 4.84 & 3.53 & 4.19 & 3.59 & 3.17 & 4.37 & 3.08 & 3.83 \\
\hline $\mathrm{Eu}$ & 1.09 & 1.36 & 1.11 & 1.33 & 1.12 & 0.95 & 1.32 & 0.95 & 1.20 \\
\hline Gd & 3.6 & 4.4 & 3.6 & 3.8 & 3.5 & 3.1 & 4.0 & 2.9 & 3.5 \\
\hline $\mathrm{Tb}$ & 0.59 & 0.71 & 0.60 & 0.57 & 0.56 & 0.52 & 0.61 & 0.46 & 0.55 \\
\hline Dy & 3.41 & 4.05 & 3.59 & 3.03 & 3.22 & 2.93 & 3.24 & 2.66 & 3.11 \\
\hline Ho & 0.71 & 0.81 & 0.74 & 0.59 & 0.65 & 0.59 & 0.62 & 0.53 & 0.63 \\
\hline Er & 1.89 & 2.20 & 2.01 & 1.53 & 1.68 & 1.54 & 1.61 & 1.43 & 1.66 \\
\hline Tm & 0.29 & 0.34 & 0.31 & 0.23 & 0.26 & 0.24 & 0.25 & 0.22 & 0.26 \\
\hline $\mathrm{Yb}$ & 1.90 & 2.15 & 1.95 & 1.43 & 1.58 & 1.51 & 1.57 & 1.37 & 1.59 \\
\hline $\mathrm{Lu}$ & 0.32 & 0.35 & 0.32 & 0.23 & 0.25 & 0.25 & 0.26 & 0.23 & 0.26 \\
\hline$\Sigma \mathrm{REE}$ & 91.34 & 114.00 & 78.02 & 90.87 & 74.18 & 69.07 & 97.76 & 69.69 & 89.23 \\
\hline LREE/HREE & 6.18 & 6.60 & 4.97 & 6.97 & 5.34 & 5.49 & 7.07 & 6.09 & 6.69 \\
\hline $\mathrm{Eu} / \mathrm{Eu}^{*}$ & 0.88 & 0.89 & 0.95 & 1.00 & 0.96 & 0.92 & 0.95 & 0.95 & 0.98 \\
\hline $\mathrm{Ce} / \mathrm{Ce}^{*}$ & 0.89 & 0.92 & 0.91 & 0.96 & 0.90 & 0.88 & 0.92 & 0.90 & 0.89 \\
\hline $\mathrm{La}_{\mathrm{N}} / \mathrm{Yb}_{\mathrm{N}}$ & 6.12 & 6.35 & 4.58 & 7.09 & 5.35 & 5.51 & 7.47 & 6.15 & 7.06 \\
\hline $\mathrm{Rb}$ & 111 & 153 & 332 & 82 & 64 & 61 & 86 & 66 & 88 \\
\hline $\mathrm{Ba}$ & 801 & 787 & 173 & 960 & 346 & 309 & 636 & 386 & 466 \\
\hline $\mathrm{Th}$ & 5.06 & 5.64 & 3.05 & 3.04 & 2.32 & 3.44 & 3.36 & 3.25 & 3.55 \\
\hline $\mathrm{U}$ & 0.97 & 1.12 & 0.72 & 0.76 & 0.62 & 0.80 & 0.76 & 0.75 & 0.96 \\
\hline $\mathrm{Ta}$ & 0.3 & 0.6 & 0.3 & 0.5 & 0.3 & 0.3 & 0.5 & 0.4 & 0.4 \\
\hline $\mathrm{Nb}$ & 3.5 & 6.8 & 3.8 & 6.2 & 3.2 & 3.1 & 6.3 & 3.3 & 4.3 \\
\hline $\mathrm{Sr}$ & 412 & 513 & 310 & 360 & 316 & 308 & 390 & 378 & 510 \\
\hline $\mathrm{Zr}$ & 111 & 160 & 98 & 126 & 98 & 99 & 132 & 104 & 116 \\
\hline Hf & 3.1 & 5.4 & 2.5 & 3.7 & 2.7 & 2.8 & 3.3 & 3.0 & 3.1 \\
\hline $\mathrm{Y}$ & 18.9 & 20.7 & 18.2 & 15.1 & 16.0 & 15.3 & 15.9 & 12.9 & 16.4 \\
\hline $\mathrm{Th} / \mathrm{Ta}$ & 18.21 & 9.36 & 10.07 & 5.96 & 8.46 & 10.02 & 7.42 & 8.88 & 10.03 \\
\hline $\mathrm{Nb} / \mathrm{U}$ & 3.58 & 6.09 & 5.32 & 8.19 & 5.17 & 3.92 & 8.28 & 4.40 & 4.51 \\
\hline $\mathrm{Nb} / \mathrm{La}$ & 0.20 & 0.34 & 0.29 & 0.41 & 0.26 & 0.25 & 0.36 & 0.27 & 0.26 \\
\hline $\mathrm{Nb} / \mathrm{Ta}$ & 12.51 & 11.35 & 12.56 & 12.15 & 11.74 & 9.09 & 13.91 & 9.04 & 12.21 \\
\hline $\mathrm{Zr} / \mathrm{Hf}$ & 35.86 & 29.77 & 39.91 & 34.22 & 36.71 & 35.01 & 40.18 & 35.17 & 36.99 \\
\hline $\mathrm{Nb} / \mathrm{Yb}$ & 1.83 & 3.18 & 1.95 & 4.35 & 2.04 & 2.07 & 4.03 & 2.41 & 2.71 \\
\hline $\mathrm{K}^{*}$ & 4.76 & 3.82 & 5.41 & 4.15 & 4.42 & 3.16 & 4.21 & 3.58 & 4.04 \\
\hline $\mathrm{Nb}^{*}$ & 0.10 & 0.17 & 0.12 & 0.19 & 0.12 & 0.15 & 0.17 & 0.14 & 0.13 \\
\hline Sr* & 1.20 & 1.16 & 1.08 & 1.00 & 1.14 & 1.20 & 1.02 & 1.44 & 1.50 \\
\hline
\end{tabular}


Table 1. (Continued.)

\begin{tabular}{|c|c|c|c|c|c|c|c|c|c|}
\hline Sample no. & $81-2-1$ & $85-3$ & $87-1$ & $88-4-2$ & $810-2$ & $813-1$ & $816-1-2$ & $821-4$ & $811-1$ \\
\hline $\mathrm{SiO}_{2}(\%)$ & 54.02 & 50.85 & 53.36 & 50.91 & 50.03 & 53.39 & 52.86 & 50.56 & 49.42 \\
\hline $\mathrm{TiO}_{2}$ & 0.75 & 1.06 & 0.63 & 0.95 & 1.08 & 0.78 & 0.77 & 0.81 & 1.07 \\
\hline $\mathrm{Al}_{2} \mathrm{O}_{3}$ & 15.0 & 17.0 & 15.4 & 16.3 & 17.6 & 16.1 & 17.0 & 13.9 & 16.2 \\
\hline $\mathrm{Fe}_{2} \mathrm{O}_{3}$ & 2.46 & 2.94 & 2.05 & 2.43 & 3.01 & 2.40 & 2.80 & 3.00 & 3.07 \\
\hline $\mathrm{FeO}$ & 4.69 & 5.18 & 4.60 & 4.64 & 5.80 & 5.11 & 4.92 & 5.63 & 5.61 \\
\hline $\mathrm{MnO}$ & 0.13 & 0.14 & 0.13 & 0.11 & 0.15 & 0.12 & 0.13 & 0.17 & 0.14 \\
\hline $\mathrm{MgO}$ & 8.08 & 5.51 & 7.92 & 5.74 & 4.66 & 6.93 & 6.74 & 10.47 & 7.43 \\
\hline $\mathrm{CaO}$ & 5.96 & 8.91 & 6.13 & 4.57 & 7.37 & 6.40 & 6.90 & 8.74 & 7.15 \\
\hline $\mathrm{Na}_{2} \mathrm{O}$ & 3.64 & 3.19 & 3.24 & 4.26 & 4.06 & 3.09 & 3.47 & 1.61 & 2.89 \\
\hline $\mathrm{K}_{2} \mathrm{O}$ & 1.81 & 1.82 & 1.69 & 1.75 & 1.89 & 1.53 & 1.42 & 0.92 & 2.41 \\
\hline $\mathrm{P}_{2} \mathrm{O}_{5}$ & 0.14 & 0.29 & 0.12 & 0.25 & 0.22 & 0.11 & 0.16 & 0.12 & 0.28 \\
\hline LOI & 2.31 & 2.29 & 3.15 & 5.70 & 2.04 & 2.36 & 1.56 & 2.91 & 2.38 \\
\hline TOTAL & 98.95 & 99.13 & 98.39 & 97.57 & 97.91 & 98.29 & 98.78 & 98.88 & 98.02 \\
\hline $\mathrm{Na}_{2} \mathrm{O}+\mathrm{K}_{2} \mathrm{O}$ & 5.45 & 5.01 & 4.93 & 6.01 & 5.95 & 4.62 & 4.89 & 2.53 & 5.30 \\
\hline $\mathrm{A} / \mathrm{NK}$ & 1.88 & 2.35 & 2.15 & 1.83 & 2.02 & 2.38 & 2.35 & 3.82 & 2.20 \\
\hline $\mathrm{A} / \mathrm{CNK}$ & 0.80 & 0.72 & 0.84 & 0.95 & 0.80 & 0.87 & 0.86 & 0.71 & 0.79 \\
\hline $\mathrm{Mg}^{\#}$ & 68 & 56 & 69 & 60 & 49 & 63 & 62 & 69 & 61 \\
\hline $\mathrm{FeO}_{\text {total }}$ & 6.91 & 7.83 & 6.44 & 6.82 & 8.51 & 7.27 & 7.44 & 8.33 & 8.37 \\
\hline La (ppm) & 14.9 & 21.0 & 12.8 & 24.7 & 20.0 & 11.5 & 14.7 & 14.8 & 25.4 \\
\hline $\mathrm{Ce}$ & 30.9 & 42.0 & 26.2 & 50.2 & 40.8 & 24.3 & 31.3 & 31.2 & 49.4 \\
\hline $\operatorname{Pr}$ & 3.98 & 5.65 & 3.51 & 6.16 & 5.21 & 3.21 & 4.00 & 4.20 & 6.35 \\
\hline $\mathrm{Nd}$ & 17.2 & 24.4 & 15.1 & 26.1 & 22.7 & 13.9 & 17.4 & 17.8 & 26.5 \\
\hline $\mathrm{Sm}$ & 3.69 & 5.16 & 3.27 & 5.07 & 4.82 & 3.24 & 3.85 & 4.13 & 5.38 \\
\hline $\mathrm{Eu}$ & 1.03 & 1.57 & 1.03 & 1.48 & 1.50 & 0.98 & 1.13 & 1.08 & 1.69 \\
\hline Gd & 3.4 & 4.5 & 3.0 & 4.1 & 4.3 & 3.2 & 3.5 & 4.1 & 4.5 \\
\hline $\mathrm{Tb}$ & 0.48 & 0.62 & 0.44 & 0.55 & 0.64 & 0.48 & 0.50 & 0.61 & 0.62 \\
\hline Dy & 2.97 & 3.74 & 2.74 & 3.35 & 4.10 & 3.05 & 3.08 & 4.02 & 3.89 \\
\hline Но & 0.58 & 0.70 & 0.54 & 0.63 & 0.79 & 0.59 & 0.64 & 0.79 & 0.73 \\
\hline Er & 1.69 & 1.90 & 1.58 & 1.84 & 2.43 & 1.71 & 1.81 & 2.35 & 2.06 \\
\hline $\mathrm{Tm}$ & 0.23 & 0.26 & 0.21 & 0.26 & 0.33 & 0.23 & 0.26 & 0.32 & 0.29 \\
\hline $\mathrm{Yb}$ & 1.57 & 1.71 & 1.39 & 1.69 & 2.22 & 1.54 & 1.73 & 2.18 & 1.90 \\
\hline $\mathrm{Lu}$ & 0.24 & 0.26 & 0.21 & 0.24 & 0.33 & 0.22 & 0.24 & 0.32 & 0.28 \\
\hline ¿REE & 82.84 & 113.50 & 72.05 & 126.40 & 110.19 & 68.11 & 84.12 & 87.85 & 128.95 \\
\hline LREE/HREE & 6.44 & 7.27 & 6.11 & 8.96 & 6.27 & 5.20 & 6.17 & 5.00 & 8.06 \\
\hline $\mathrm{Eu} / \mathrm{Eu}^{*}$ & 0.88 & 0.97 & 0.98 & 0.96 & 0.99 & 0.93 & 0.93 & 0.80 & 1.03 \\
\hline $\mathrm{Ce} / \mathrm{Ce}^{*}$ & 0.93 & 0.89 & 0.91 & 0.93 & 0.92 & 0.93 & 0.94 & 0.92 & 0.89 \\
\hline $\mathrm{La}_{\mathrm{N}} / \mathrm{Yb}_{\mathrm{N}}$ & 6.41 & 8.30 & 6.22 & 9.88 & 6.09 & 5.05 & 5.74 & 4.59 & 9.03 \\
\hline $\mathrm{Rb}$ & 72 & 59 & 74 & 69 & 53 & 65 & 46 & 71 & 97 \\
\hline $\mathrm{Ba}$ & 460 & 478 & 382 & 1210 & 752 & 423 & 616 & 301 & 932 \\
\hline $\mathrm{Th}$ & 3.92 & 3.54 & 3.04 & 4.89 & 4.52 & 3.12 & 3.04 & 3.92 & 4.57 \\
\hline $\mathrm{U}$ & 0.88 & 0.81 & 0.82 & 1.03 & 0.93 & 0.70 & 0.64 & 0.75 & 0.96 \\
\hline $\mathrm{Ta}$ & 1.2 & 0.9 & 1.9 & 0.6 & 1.6 & 0.6 & 2.6 & 1.3 & 2.8 \\
\hline $\mathrm{Nb}$ & 5.1 & 7.3 & 4.2 & 5.8 & 6.3 & 3.2 & 3.9 & 5.2 & 8.5 \\
\hline $\mathrm{Sr}$ & 588 & 416 & 716 & 782 & 707 & 388 & 569 & 358 & 500 \\
\hline $\mathrm{Zr}$ & 114 & 130 & 100 & 132 & 112 & 96 & 112 & 97 & 148 \\
\hline Hf & 3.2 & 3.4 & 2.9 & 3.6 & 3.2 & 2.8 & 3.2 & 2.9 & 3.9 \\
\hline $\mathrm{Y}$ & 17.0 & 20.8 & 15.4 & 18.4 & 24.0 & 17.2 & 18.4 & 23.1 & 21.1 \\
\hline $\mathrm{Th} / \mathrm{Ta}$ & 3.27 & 3.93 & 1.60 & 8.15 & 2.83 & 5.20 & 1.17 & 3.02 & 1.63 \\
\hline $\mathrm{Nb} / \mathrm{U}$ & 3.58 & 6.09 & 5.32 & 8.19 & 5.17 & 3.92 & 8.28 & 4.51 & 5.80 \\
\hline
\end{tabular}


Table 1. (Continued.)

\begin{tabular}{|c|c|c|c|c|c|c|c|c|c|}
\hline Sample no. & $81-2-1$ & $85-3$ & $87-1$ & $88-4-2$ & $810-2$ & $813-1$ & $816-1-2$ & $821-4$ & $811-1$ \\
\hline $\mathrm{Nb} / \mathrm{La}$ & 0.34 & 0.35 & 0.33 & 0.23 & 0.32 & 0.28 & 0.27 & 0.35 & 0.33 \\
\hline $\mathrm{Nb} / \mathrm{Ta}$ & 4.25 & 8.11 & 2.21 & 9.67 & 3.94 & 5.33 & 1.50 & 4.00 & 3.04 \\
\hline $\mathrm{Zr} / \mathrm{Hf}$ & 35.63 & 38.24 & 34.48 & 36.67 & 35.00 & 34.29 & 35.00 & 33.45 & 37.95 \\
\hline $\mathrm{Nb} / \mathrm{Yb}$ & 3.25 & 4.27 & 3.02 & 3.43 & 2.84 & 2.08 & 2.25 & 2.39 & 4.47 \\
\hline $\mathrm{K}^{*}$ & 2.97 & 3.21 & 2.22 & 2.81 & 1.62 & 2.65 & 1.80 & 2.49 & 1.14 \\
\hline $\mathrm{Nb}^{*}$ & 0.15 & 0.18 & 0.13 & 0.15 & 0.21 & 0.15 & 0.11 & 0.17 & 0.25 \\
\hline $\mathrm{Sr}^{*}$ & 1.85 & 0.95 & 2.62 & 1.56 & 1.69 & 1.54 & 1.77 & 1.10 & 1.00 \\
\hline
\end{tabular}

$\mathrm{Mg}^{\#}=100 \mathrm{Mg}^{2+} /\left(\mathrm{Mg}^{2+}+\mathrm{FeO}_{\text {total }}\right), \mathrm{FeO}_{\text {total }}=\mathrm{FeO}+0.8998 \times \mathrm{Fe}_{2} \mathrm{O}_{3}, \mathrm{~K}^{*}=2 \mathrm{~K}_{\mathrm{N}} /\left(\mathrm{Ta}_{\mathrm{N}}+\mathrm{La}_{\mathrm{N}}\right), \mathrm{Nb}^{*}=2 \mathrm{Nb}_{\mathrm{N}} /\left(\mathrm{K}_{\mathrm{N}}+\mathrm{La}_{\mathrm{N}}\right)$, $\mathrm{Sr}^{*}=2 \mathrm{Sr}_{\mathrm{N}} /\left(\mathrm{Ce}_{\mathrm{N}}+\mathrm{Nd}_{\mathrm{N}}\right)$.

magmatic zircons. Most of the zircons are transparent but dark to slightly bright except 2 grains containing bright cores (No. 06 and 08 of sample 826-1). Grain size mainly varies from $70-120$ $\mu \mathrm{m}$, with aspect ratios $2: 1$ to $3: 1$ and euhedral to slightly rounded shapes, indicating that some of them are inherited zircons trapped by ascending magma.

The 33 spots of $\mathrm{U}-\mathrm{Pb}$ analytical results from samples 821-12 and 826-1 are presented in table 2 . There are large variations for the total $\mathrm{Pb},{ }^{232} \mathrm{Th}$, ${ }^{238} \mathrm{U}$ contents and distinct ${ }^{206} \mathrm{~Pb} /{ }^{238} \mathrm{U}$ ages ranging 435-2132 Ma. However, most of the ages cluster at $\sim 440 \mathrm{Ma}$ while the other ages are scattered (figure 8a-d). Previous research suggested that a series of magmatic activities occurred in the NCC from the late Paleoproterozoic to Neoproterozoic: formation of a large igneous province $(\sim 1.78 \mathrm{Ga})$, anorogenic magmatic activity $(1.72-1.62 \mathrm{Ga})$, diabase sill intrusions (1.35-1.32 Ga) and mafic dyke swarm intrusions ( 900 Ma) (Zhai et al. 2014). Conforming to these magmatic events, the age of inherited zircons in the study reflect the assimilation of the old basement of NCC during magma ascent. After removing unreliable data with concordance less than $90 \%$, the zircons dated $\sim 400-500$ Ma can be considered representative of the formation age of the mafic rocks; while those with scattered and old ages may be inherited zircons. Eventually, 9 spots of $821-12$ and 13 spots of 826-1 (noted as magmatic zircons in table 2) were selected to calculate the formation age of the diabase. Zircons from 821-12 yielded a concordant $\mathrm{U}-\mathrm{Pb}$ age of $437.6 \pm 5.8 \mathrm{Ma}(\mathrm{MSWD}=0.25)$ and a weighted mean $\mathrm{U}-\mathrm{Pb}$ age of $437.6 \pm 2.7 \mathrm{Ma}$ $(\mathrm{MSWD}=0.33)$. Within the age error of sample 821-12, zircons from 826-1 gave a concordant age of $442.6 \pm 9.2 \mathrm{Ma}(\mathrm{MSWD}=0.18)$ and a weighted mean age of $440.5 \pm 2.3 \mathrm{Ma}(\mathrm{MSWD}=0.28$ ) (figure $8 \mathrm{e}, \mathrm{f}$ ). Thus, the mafic rocks in the Taipusi area are estimated to have intruded during 440 Ma.

\subsection{Trace elements of zircons}

Magmatic zircon trace element analysis results are shown in table 3. Due to the similarity of the samples in element concentration, their geochemical characteristics are described together. These zircons have high average Hf values of 31,300 ppm. Titanium concentrations mainly vary from 10-33 ppm (averaging at $17 \mathrm{ppm}$ ) except one zircon possessing $465 \mathrm{ppm}$. In addition, these zircons have low average values of $\mathrm{Nb}(9.1 \mathrm{ppm})$ and $\mathrm{Ta}$ (4.1 ppm) concentrations. Meanwhile, the Th/U ratios are greater than 0.4 with an average value of 0.71 .

The chondrite-normalized REE patterns of the zircons are strongly enriched in heavy REEs relative to light REEs (figure 9a, b). $\Sigma$ REE concentrations range from 960 to $3853 \mathrm{ppm}$ with an average value of $1956 \mathrm{ppm}$. These zircons possess medium negative $\mathrm{Eu}$ anomalies with $\mathrm{Eu} / \mathrm{Eu}^{*}$ varying from $0.16-0.68$ (averaging 0.41 ) and pronounced positive Ce anomalies with $\mathrm{Ce} / \mathrm{Ce}^{*}$ ranging from 3.3-47.9 (averaging 25.7).

\section{Discussion}

\subsection{Timing of dikes in Taipusi area}

Dikes exposed in the Taipusi area are mainly composed of mafic rocks such as gabbro, diabase and lamprophyre. The zircons from these mafic rocks have long columnar, idiomorphic crystal shapes with high $\mathrm{Th} / \mathrm{U}$ ratios. They show clear oscillatory zoning in CL images, indicating a magmatic origin. Hoskin (2005) demonstrated that there exists a distinct discrepancy of REE distribution patterns between magmatic zircons and hydrothermal zircons. Compared to magmatic zircons, hydrothermal zircons have flat LREE concentration patterns, higher REE concentration and slight positive Ce 

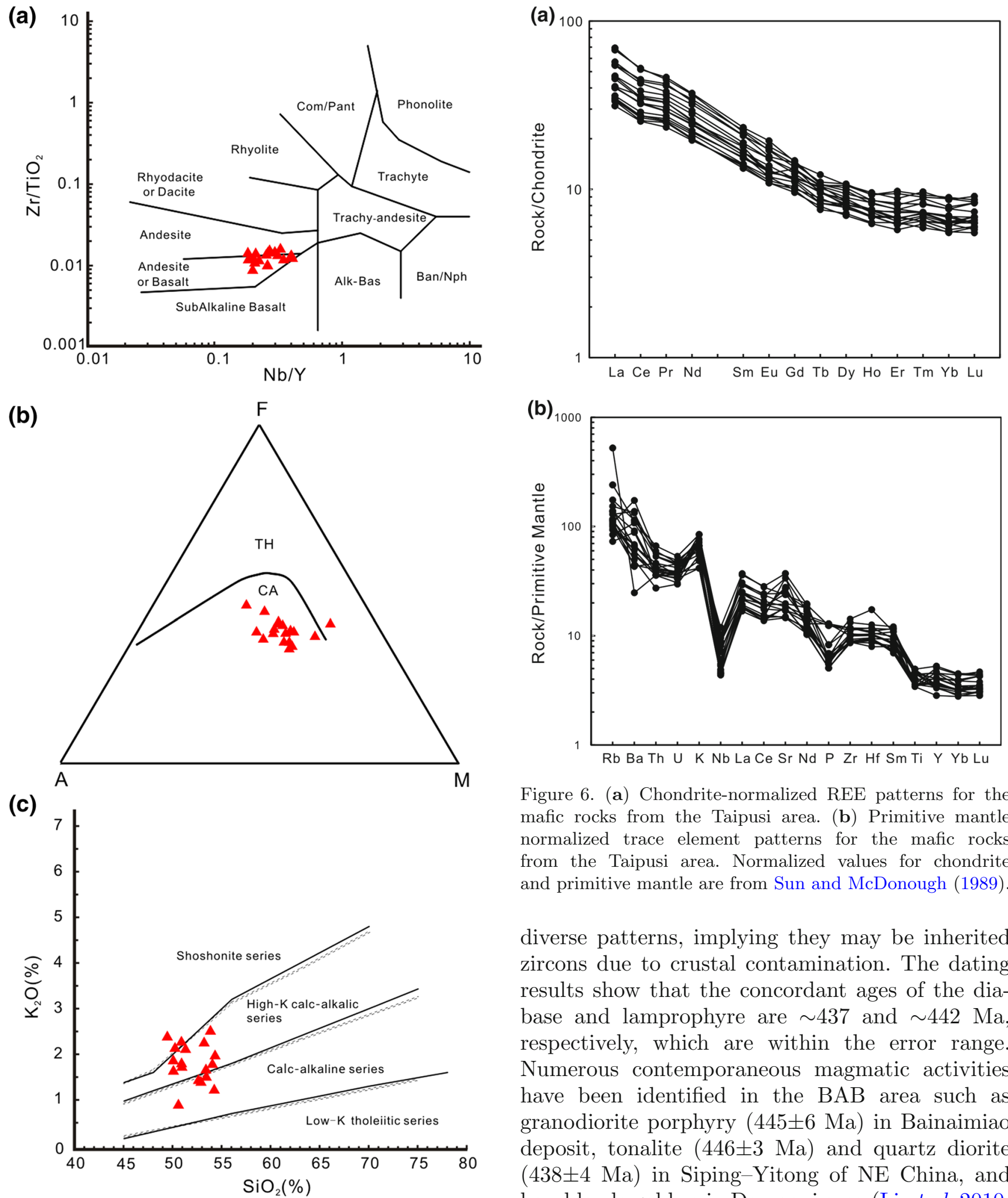

Figure 5. (a) $\mathrm{Zr} / \mathrm{TiO}_{2}$ vs. $\mathrm{Nb} / \mathrm{Y}$ diagram (after Winchester and Floyd 1977), (b) AFM diagram (after Irvine and Baragar 1971), TH: tholeiite series; CA: calc-alkaline series and (c) $\mathrm{SiO}_{2}$ vs. $\mathrm{K}_{2} \mathrm{O}$ diagram (after Peccerillo and Taylor 1976).

anomaly. As shown in figure $9(\mathrm{a}, \mathrm{b})$, all the zircons show typical features of magmatic zircons although several zircons with older ages display

Figure 6. (a) Chondrite-normalized REE patterns for the mafic rocks from the Taipusi area. (b) Primitive mantle normalized trace element patterns for the mafic rocks from the Taipusi area. Normalized values for chondrite and primitive mantle are from Sun and McDonough (1989).

diverse patterns, implying they may be inherited zircons due to crustal contamination. The dating results show that the concordant ages of the diabase and lamprophyre are $\sim 437$ and $\sim 442 \mathrm{Ma}$, respectively, which are within the error range. Numerous contemporaneous magmatic activities have been identified in the $\mathrm{BAB}$ area such as granodiorite porphyry ( $445 \pm 6 \mathrm{Ma})$ in Bainaimiao deposit, tonalite (446 $\pm 3 \mathrm{Ma})$ and quartz diorite $(438 \pm 4 \mathrm{Ma})$ in Siping-Yitong of NE China, and hornblende gabbro in Damaoqi area (Li et al. 2010, 2012b; Zhang et al. 2014). These isotopic data conform to $\mathrm{U}-\mathrm{Pb}$ ages in this study, indicating that magmatism in $\mathrm{BAB}$ area have regional characteristics rather than influenced by local development. It confirms that the dating results are of high reliance, and thus formation period of these dikes is considered to be during the early Silurian. 


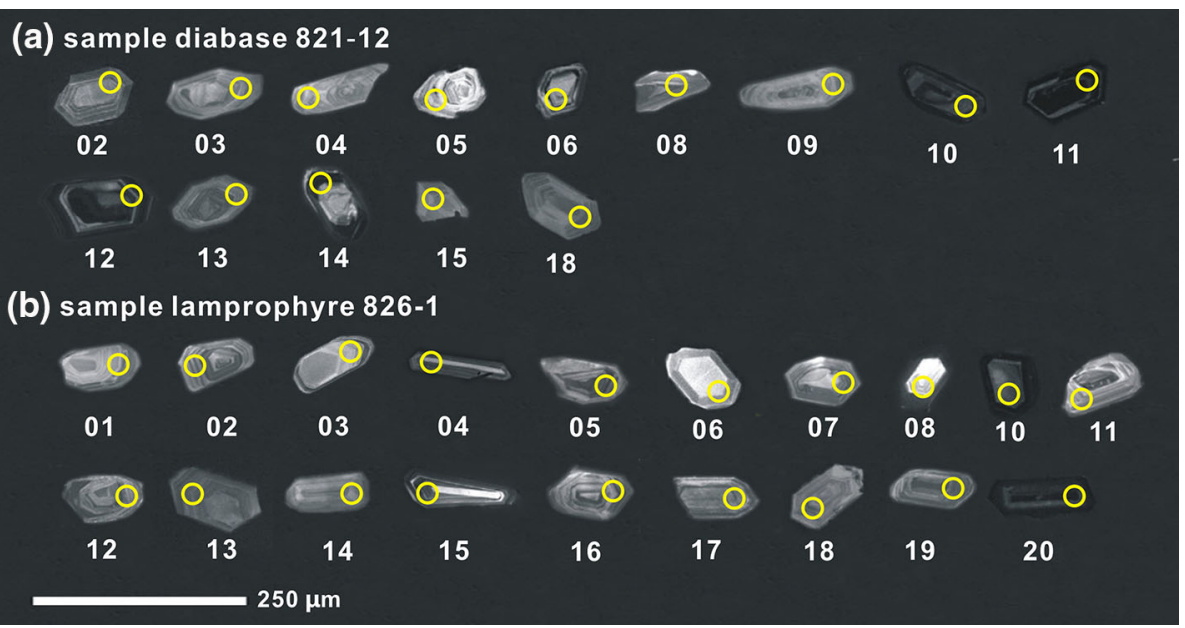

Figure 7. Zircon CL images of diabase sample 821-12 (a) and lamprophyre sample 826-1 (b) from the Taipusi area.

\subsection{Origin and evolution of the mafic magma}

\subsubsection{Whole-rock geochemical implications}

Most original mafic magmas formed by partial melting of the mantle do not undergo pronounced fractional crystallization and crustal contamination. Mafic rocks formed by original magmas are generally characterized by low compositions of $\mathrm{SiO}_{2}$ and incompatible elements (e.g., LILE, HFSE and LREE), with $\mathrm{Mg} \#$ values ranging from 65 to 75 (Jesus et al. 2014). Mafic rocks in Taipusi area are enriched in LILE and LREE but depleted in HFSE, with varied $\mathrm{Mg}$ \# values ranging 49-69 (table 1), indicating the source region evolution may have an affinity with subduction zone magmatism.

The relationship between different major-element oxides is shown in figure 10 . The negative correlation between $\mathrm{MgO}$ and $\mathrm{Al}_{2} \mathrm{O}_{3}$ indicates fractional crystallization of olivine during the magma evolutionary process (figure 10a), and the positive correlation of $\mathrm{MgO}$ vs. $\mathrm{CaO}$ and $\mathrm{CaO}$ vs. $\mathrm{CaO} / \mathrm{Al}_{2} \mathrm{O}_{3}$ implies fractional crystallization of clinopyroxene (figure 10b, c). Additionally, the negative correlation of $\mathrm{MgO}$ vs. $\mathrm{P}_{2} \mathrm{O}_{5}$ and $\mathrm{MgO}$ vs. $\mathrm{TiO}_{2}$ illustrates fractional crystallization of apatite and $\mathrm{Ti}-$ Fe oxides (figure 10d, e). The negative correlation between $\mathrm{MgO}$ and total alkaline $\left(\mathrm{Na}_{2} \mathrm{O}+\mathrm{K}_{2} \mathrm{O}\right)$ also indicates fractional crystallization of other major and accessory minerals (figure 10f). In contrast, the slightly negative Eu anomalies (average $\delta \mathrm{Eu}=0.94$ ) imply weak fractional crystallization of plagioclase.

Crustal contamination is an important evolutionary process during magma ascent. The enrichment of LILE and LREE, and the depletion of HFSE indicate that crustal materials were involved in the formation process of the mafic rocks in the Taipusi area, either at the source or during magma ascent and evolution (Wang et al. 2012; Zhao et al. 2014). The weak negative Ce anomalies (average $\delta \mathrm{Ce}=0.91)$ may imply that crustal materials with depleted Ce were incorporated into the magma. The depletion of $\mathrm{Nb}$ and $\mathrm{Ta}$ may indicate that crustal or source contamination occurred during the magma intrusive process. The $\mathrm{Th} / \mathrm{Ta}$ ratios range from 1.17 to 18.21 (average 6.62) and are mostly higher than 2.07 value of primitive mantle (Sun and McDonough 1989), also suggesting pronounced crustal contamination. High primitive mantle-normalized $\mathrm{Tb} / \mathrm{Ta}$ ratios $\left((\mathrm{Tb} / \mathrm{Ta})_{\mathrm{N}}>1\right)$ and low $\mathrm{Nb} / \mathrm{La}$ ratios $(\mathrm{Nb} / \mathrm{La}<1)$ are two reliable indicators for crustal contamination (Kieffer et al. 2004). The mafic rocks in the Taipusi area have ratios of $(\mathrm{Tb} / \mathrm{Ta})_{\mathrm{N}}>1$ and $\mathrm{Nb} / \mathrm{La}<1$ (table 1$)$, also implying that it may have undergone significant upper crustal contamination. Ratios of $\mathrm{Nb} / \mathrm{U}$ do not experience significant differentiation during the partial melting of mantle, and can thus be used to reflect geochemical characteristics of magma source region. The $\mathrm{Nb} / \mathrm{U}$ ratios of mafic rocks in the Taipusi area range from 3.58 to 8.28 , which are lower than that of primitive mantle $(\sim 34$, Sun and McDonough 1989) and close to that of continental crust (9-12, Hofmann 1988), also suggesting that the magma underwent crustal contamination. The ratios of $\mathrm{Nb} / \mathrm{Ta}$ range from 1.50 to 13.91 with an average value of 8.14 , which are also distinguished from that of primitive mantle (17.39, Sun and McDonough 1989). Ratios of elements with 
similar total partition coefficients would not be influenced by fractional crystallization and degree of partial melting; thus their correlation can be used to determine the existence and degree of crustal contamination. As shown in figure 11(ad), the linear correlations of $\mathrm{Zr} v s$. Th, $\mathrm{Nb}$ vs. Th, $\mathrm{Nb} / \mathrm{Ta}$ vs. $\mathrm{La} / \mathrm{Yb}$ and $\mathrm{La} / \mathrm{Nb}$ vs. $\mathrm{Zr} / \mathrm{Nb}$ imply that assimilation and crustal contamination occurred during the crystallization process. Moreover, the considerably varied $\mathrm{Th}$ and $\mathrm{U}$ contents as well as different ${ }^{206} \mathrm{~Pb} /{ }^{238} \mathrm{U}$ ages among zircons from the diabase also indicate that some zircons originated through capture. The information of captured zircons preserved in diabase indicates the existence of an old basement in the study area. These inherited zircons may have been incorporated in the mafic magma by way of crustal assimilation and contamination when they passed through the basement.

The characteristics of source mantle should be considered when we study magma evolutionary processes. Aside from information on fractional crystallization and crustal contamination, features of original mantle magma can also be revealed by major and trace element compositions. The $\mathrm{Zr} / \mathrm{Hf}$ ratios of mafic rocks in the Taipusi area range from 29.77 to 40.18 with an average value of 35.81. These values are close to the primitive mantle value (36.73, Sun and McDonough 1989) but significantly higher than that of continental crust ( 11, Weaver 1991). This implies that the magma originated from the mantle or its source was influenced by subduction metasomatic fluids. In the $\mathrm{Th} / \mathrm{Nb}$ vs. $\mathrm{Ce} / \mathrm{Nb}$ diagram (figure 11a), these samples clearly plot along the direction of subduction-derived components, which are close to arc field and far away from crustal material field. This indicates a mantle wedge magmatic source that was modified by subduction metasomatic aqueous fluids released by dehydration; and that the continental crust component played an insignificant role in the source region. In addition, a better identification of the impact of subduction metasomatic fluids and crustal sediments on source evolution is illustrated on the $\mathrm{Ba} / \mathrm{Zr}$ vs. $\mathrm{Th} / \mathrm{Zr}$ plot (figure 11b), which shows an evolutionary tendency towards altered oceanic crustal fluids. This is further reflected by the $\mathrm{Nb} / \mathrm{Y}$ vs. La/Yb plot (figure 11c), on which most of the samples plot in the fluid-induced metamorphism field. These plots confirm that slab-derived fluids contributed significantly to the generation and evolution of the magma rather than influence from subducted sediment and the melt. Immobile elements, such as $\mathrm{Nb}, \mathrm{Yb}$ and $\mathrm{Zr}$, are employed to discriminate the nature of the magma source. Ratios of $\mathrm{Nb} / \mathrm{Yb}$ can provide a robust indicator of mantle fertility (Pearce and Stern 2006; Xu et al. 2014). In the diagram of $\mathrm{Zr} / \mathrm{Yb}$ vs. $\mathrm{Nb} / \mathrm{Yb}$ (figure $11 \mathrm{~d}$ ), $\mathrm{Nb} / \mathrm{Yb}$ ratios of the mafic rocks in the Taipusi area are in a range of $1.83-4.47$, most of which are higher than that of N-MORB (0.76, Sun and McDonough 1989) and approach values of E-MORB (3.5, Sun and McDonough 1989), indicating that the mantle source of these rocks is probably an enriched mantle wedge altered by subduction fluids. LREE enrichment could also be a signature of enriched mantle source and suggests the involvement of enriched mantle components on the origin of these mafic rocks (Zhou et al. 2015). The enriched mantle is generally thought to be related to recycling of subduction crustal components (Donnelly et al. 2004). Source mantle features can be studied further by using plots of $\mathrm{Ti} / \mathrm{Yb}$ vs. $\mathrm{Nb} / \mathrm{Yb}$ (figure 11e) and $\mathrm{Th} / \mathrm{Yb}$ vs. $\mathrm{Nb} / \mathrm{Yb}$ (figure 11f). As shown in the diagrams, the source mantle of the mafic rocks can be identified as altered enrichment mantle related to continental arcs. Thus, we infer that source magma of the Taipusi area mafic rocks originated from an enriched mantle altered by aqueous fluids derived from the subducting plate that experienced fractional crystallization, assimilation and contamination of crustal materials to different degrees during their ascent through the lithosphere.

\subsubsection{Zircon geochemical insights}

Zircon is a host for significant fractions of $U$, Th, Hf, and the REE in the whole-rock abundance (O'Hara et al. 2001; Hoskin and Schaltegger 2003). In addition, $\mathrm{Zr}-\mathrm{Hf}$ fractionation has been reported for highly evolved magmatic systems (Bau 1996). Since most Hf-enriched zircons were found in evolved rock-types, it is likely that the Hf concentration of zircon has a positive correlation with magmatic differentiation (Hoskin et al. 2000; Hoskin and Schaltegger 2003). Meanwhile, the fractionation of $\mathrm{Zr}$ and $\mathrm{Hf}$ in zirconcrystallizing melts may be correlated with the $\mathrm{Zr} / \mathrm{Hf}$ activity coefficient ratio in the melt (Linnen and Keppler 2002). Therefore, $\mathrm{Zr} / \mathrm{Hf}$ ratio can serve as an indicator of the evolutionary degree during the magmatic differentiation process. In this study, magmatic zircons from the mafic samples have high Hf concentration values, 


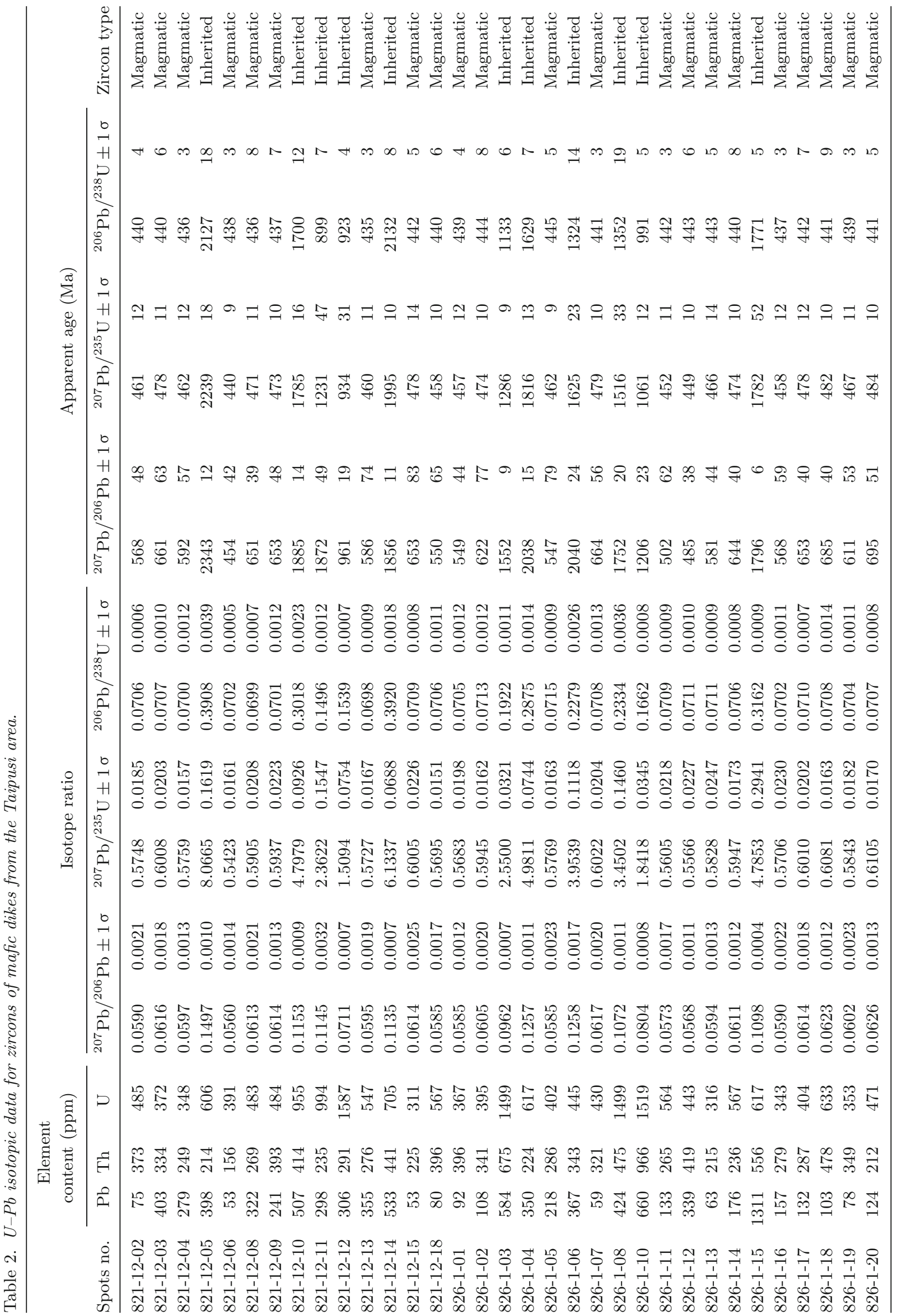



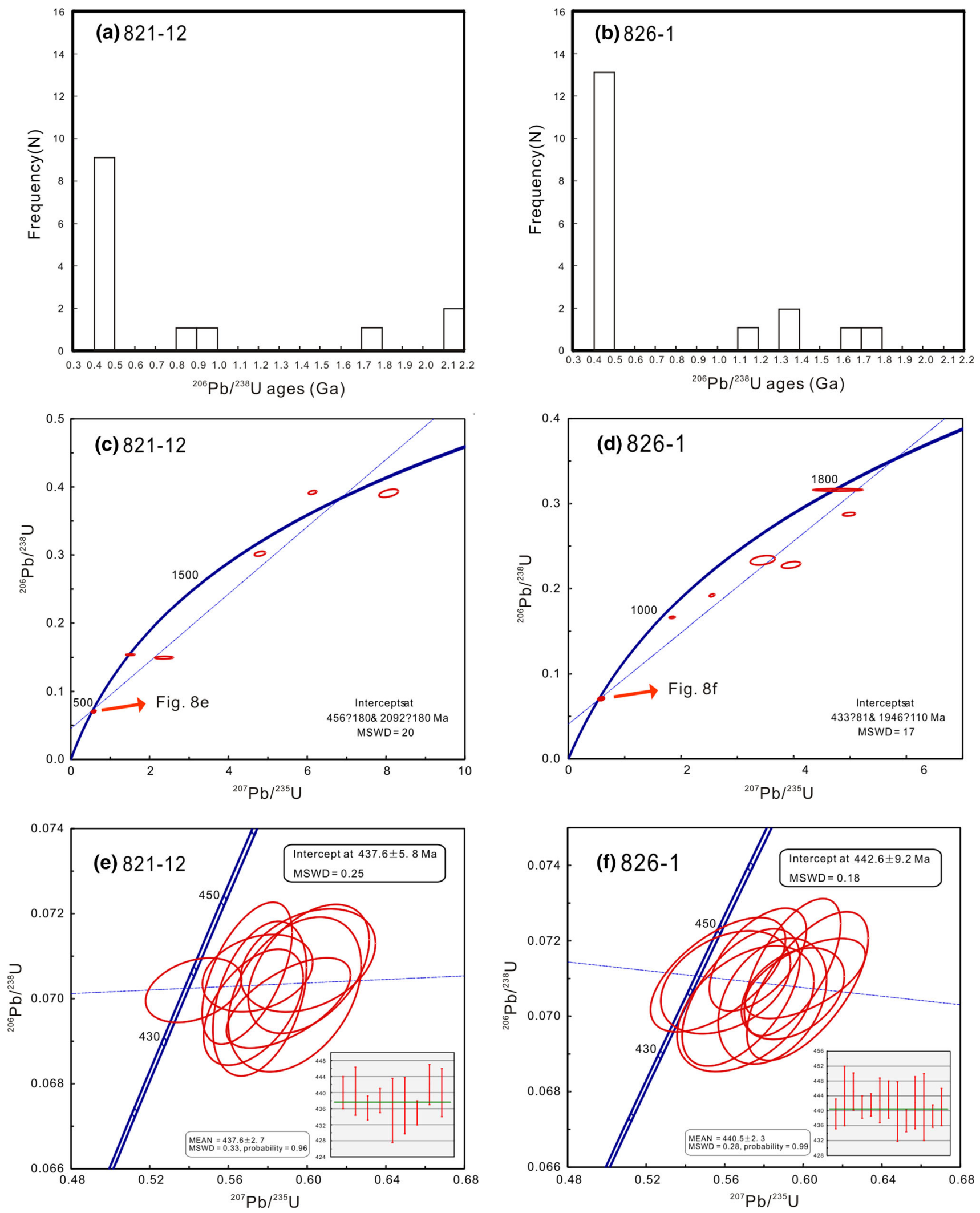

Figure 8. ( $\mathbf{a}-\mathbf{b})$ Histogram of ${ }^{206} \mathrm{~Pb} /{ }^{238} \mathrm{U}$ ages and $(\mathbf{c}-\mathbf{f})$ concordia diagram of La-ICP-MS zircon U-Pb dating results for the mafic rock samples 821-12 and 826-1 from the Taipusi area. 


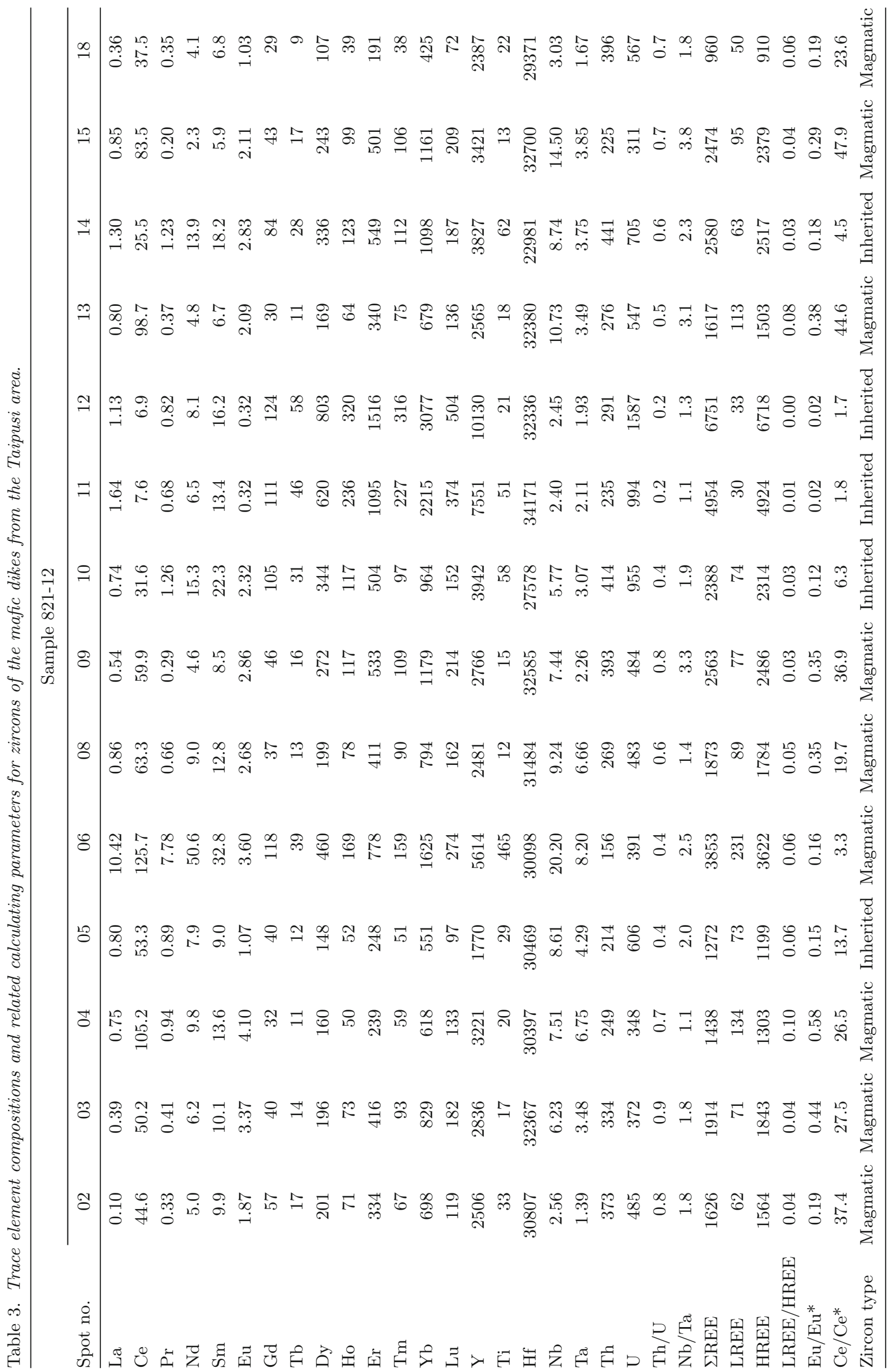




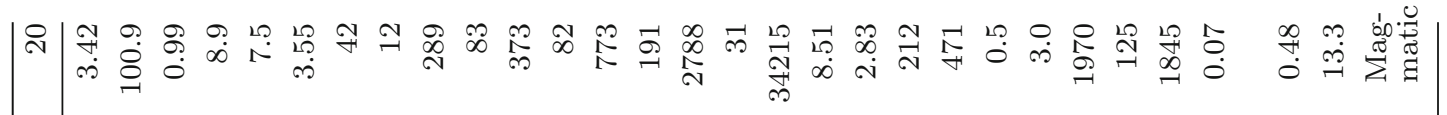

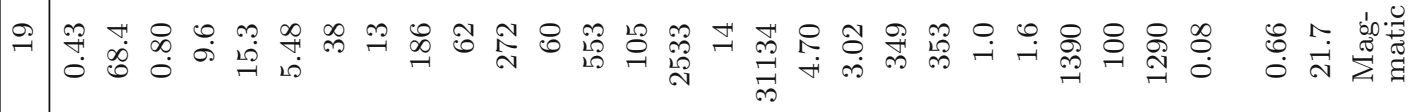

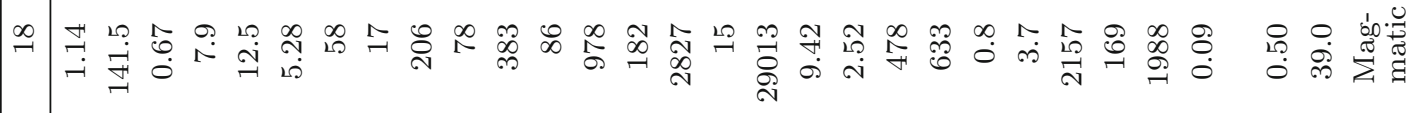

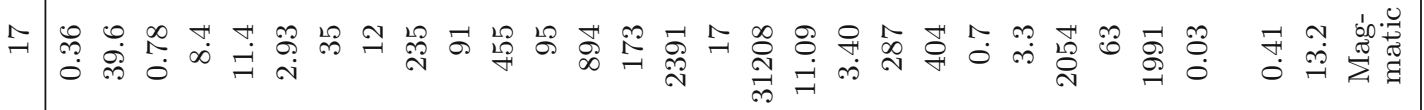

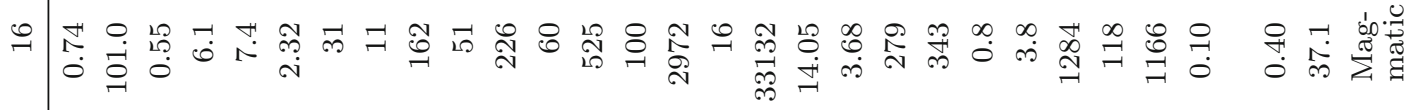

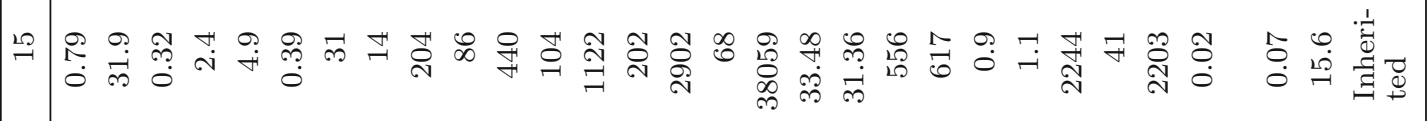

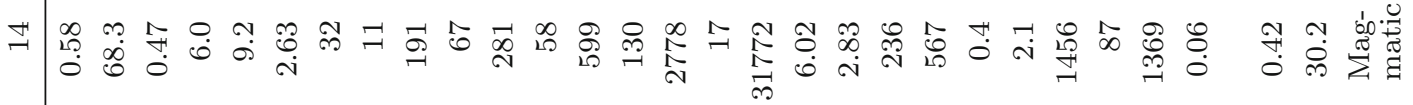

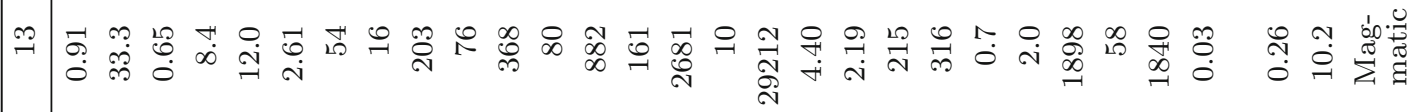

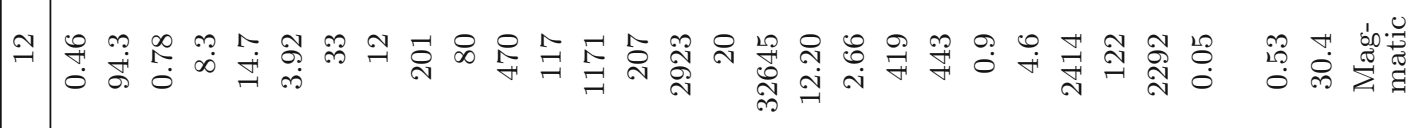

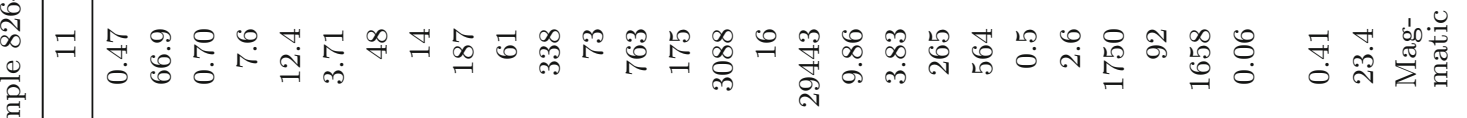
กี

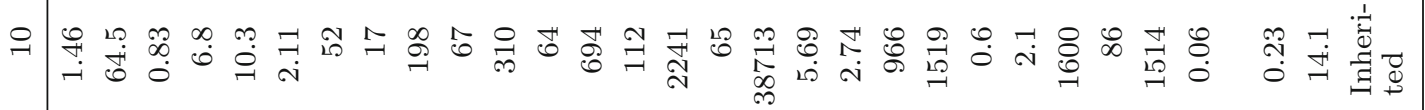

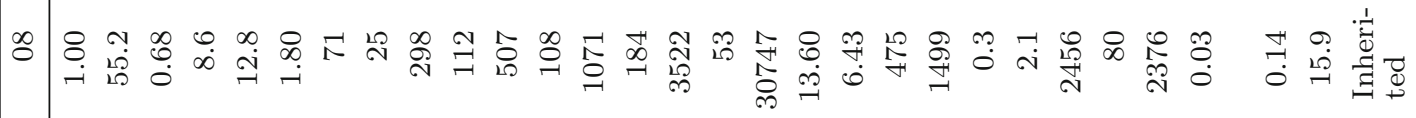

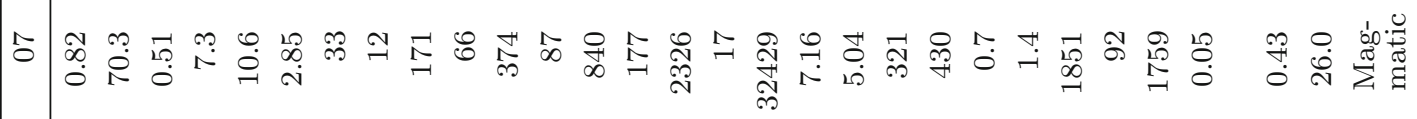

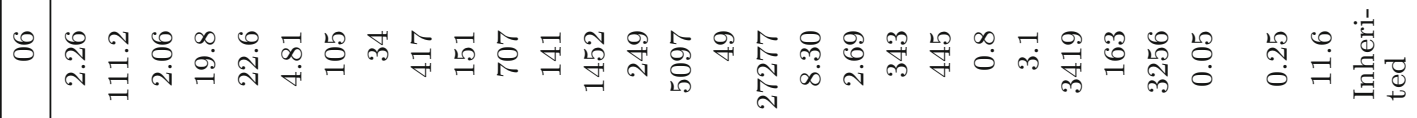

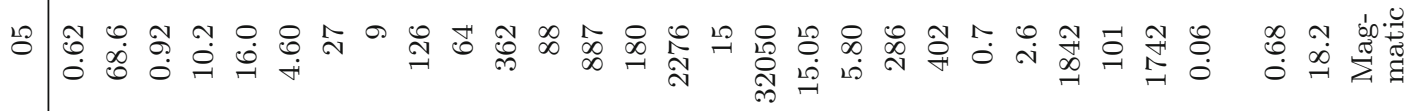

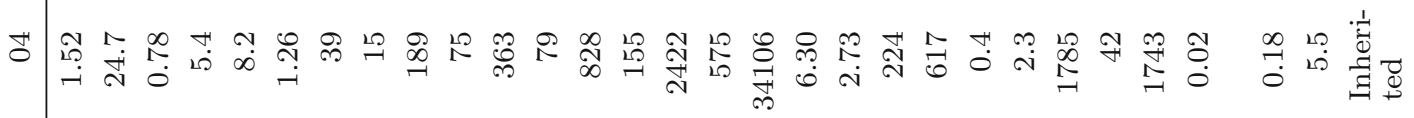

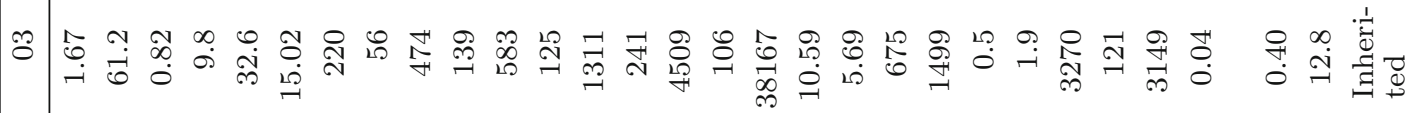

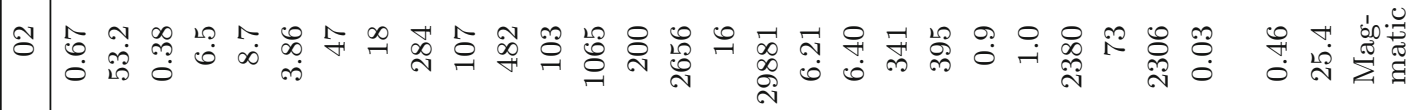

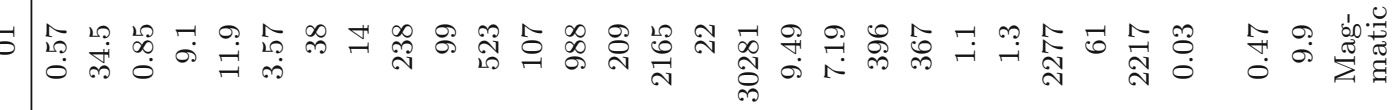

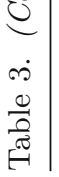

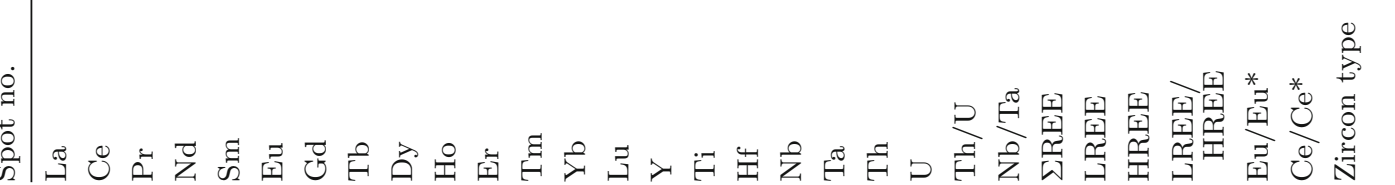



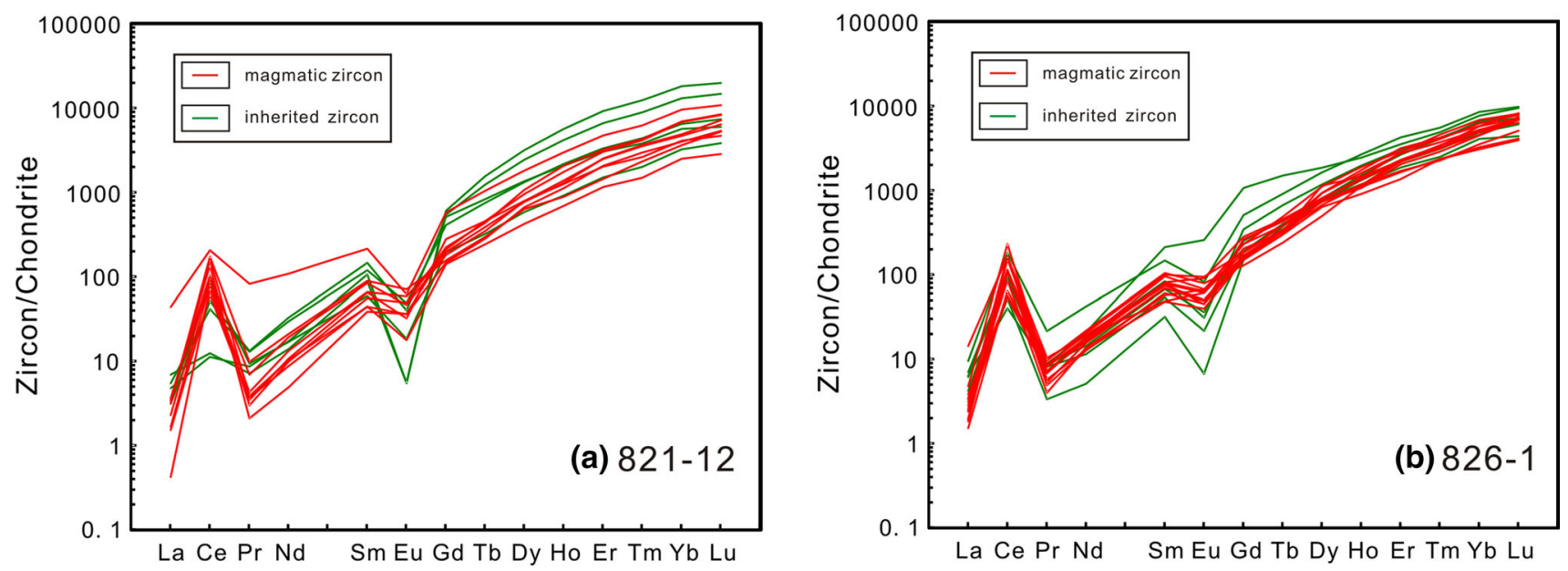

Figure 9. Chondrite-normalized REE patterns of zircons for the mafic rocks from the Taipusi area (a) sample 821-12 and (b) sample 826-1. Normalized values for chondrite are from Sun and McDonough (1989).

indicating an intensely fractionated magma origin. Moreover, zircons from highly evolved rocks are often enriched in radioactive elements such as $\mathrm{U}$, $\mathrm{Th}$ and $\mathrm{Pb}$. In zircons, $\mathrm{U}$ and $\mathrm{Th}$ can replace $\mathrm{Zr}$; $\mathrm{Th}$ and $\mathrm{U}$ are positively correlated with $\mathrm{Y}$ and REE; and $\mathrm{Y}$ and $\mathrm{Yb} / \mathrm{Sm}$ increase with increasing fractional crystallization. All of this reflects the evolutionary trend of magma. Highly evolved magma contains higher incompatible elements (Belousova et al. 2002, 2006; Li et al. $2014,2017)$. In this study, magmatic zircons of samples 821-12 and 826-1 have high average values of $\mathrm{U}, \mathrm{Th}, \mathrm{Pb}$ and $\mathrm{Y}$, suggesting that the mafic rocks at the Taipusi area were derived from a wellevolved magma.

It has been recognized that Eu may exist in +2 or +3 states in nature and its valence state is a function of temperature and oxygen fugacity of magma. As shown in table 3, all the zircons have weak negative Eu anomalies. This suggests that parental magmas may have experienced minor feldspar fractionation before zirconium saturation, or have possessed an initial negative Eu anomaly as a result of being derived from a feldspar-rich source.

A widely accepted explanation for the positive Ce anomaly in zircons is the oxidation of $\mathrm{Ce}^{3+}$ to $\mathrm{Ce}^{4+}$ during high oxygen fugacity conditions; since the ionic radius and charge of $\mathrm{Ce}^{4+}$ is similar to $\mathrm{Zr}^{4+}$, it enters crystal lattice of zircon then replaces the latter. In contrast, the trivalent light REEs are extremely incompatible with zircon due to their differences in both charge and radius (Trail et al. 2011). It is also generally acknowledged that the magnitude of the Ce anomaly is controlled by oxygen fugacity of the magma, and can thus be used to provide information on the $f \mathrm{O}_{2}$, since high $\mathrm{fO}_{2}$ makes $\mathrm{Ce}^{3+}$ convert more easily to $\mathrm{Ce}^{4+}$ (Ballard et al. 2002; Claiborne et al. 2010; Han et al. 2013). As shown in table 3, most magmatic zircons have pronounced positive Ce anomalies, implying that the parent magma of the mafic rocks in the Taipusi area once had a medium to high $f \mathrm{O}_{2}$ during its evolutionary or ascension process. In addition, Ta can easily oxidize into $5+$ valence state while $\mathrm{Nb}$ remains in $4+$ valance state, which contributes to high $\mathrm{Nb} / \mathrm{Ta}$ ratios in zircons that formed in an oxidizing environment. The $\mathrm{Nb} / \mathrm{Ta}$ ratios of magmatic zircons from samples 821-12 and 826-1 varies from 0.97 to 4.58 with a relatively high mean value of 2.43 , also implying they were derived from an oxidizing environment.

Grimes et al. (2007) suggests an efficient way to identify zircon crystallization environment using $\mathrm{U} / \mathrm{Yb}-\mathrm{Hf}$ and $\mathrm{U} / \mathrm{Yb}-\mathrm{Y}$ diagrams. As shown in figure 12 , these magmatic zircons mainly fall into the transitional field of oceanic crust and continental fields, implying the source of magma was metasomatized by slab fluids derived from subducted oceanic slabs.

Thus, trace element analysis indicates that the magma source was associated with the southward subduction of oceanic slabs and underwent fractional crystallization and crustal contamination to different degrees during its ascent through the lithosphere, forming mafic rocks of diversified types. 

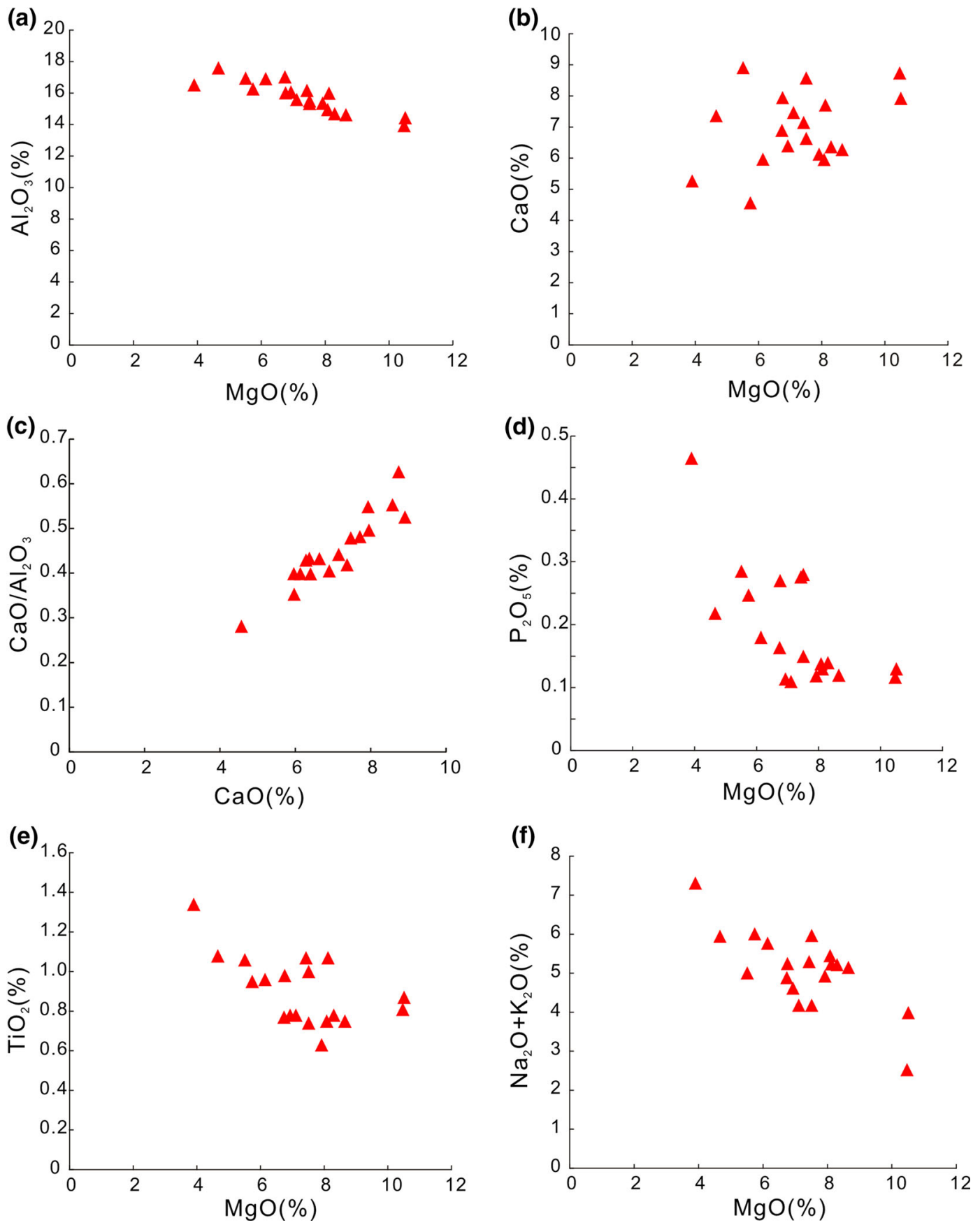

Figure 10. Discrimination diagrams of magma fractional crystallization for the mafic rocks from the Taipusi area. (a) $\mathrm{MgO}$ vs. $\mathrm{Al}_{2} \mathrm{O}_{3} ;$ (b) $\mathrm{MgO}$ vs. $\mathrm{CaO} ;$ (c) $\mathrm{CaO}$ vs. $\mathrm{CaO} / \mathrm{Al}_{2} \mathrm{O}_{3} ;$ (d) $\mathrm{MgO}$ vs. $\mathrm{P}_{2} \mathrm{O}_{5} ;(\mathbf{e}) \mathrm{MgO}$ vs. $\mathrm{TiO} \mathrm{O}_{2}$ and (f) $\mathrm{MgO}$ vs. $\mathrm{Na}_{2} \mathrm{O}+\mathrm{K}_{2} \mathrm{O}$.

\subsection{Tectonic setting}

The major element analytical results show that the mafic rocks in the Taipusi area belong to the high$\mathrm{K}$ calc-alkaline series. The average content of $\mathrm{Al}_{2} \mathrm{O}_{3}$ is $15.75 \%$, which have similar values to continental high-alumina basalt. The $\mathrm{TiO}_{2}$ content is similar to that of volcanic arc basalt. The enrichment of LILE and depletion of HFSE are consistent with the characteristics of volcanic arc rocks (Eiler et al. 2000; Grove et al. 2003; Li et al. 2013, 2016).

Furthermore, volcanic arc basalts can be subdivided into oceanic and continental types. Pearce (1983) pointed out that most basalts from active continental margins have $\mathrm{Ta} / \mathrm{Yb}$ values $>0.1$ whereas basalts from oceanic arcs have values $<0.1$. The mafic rocks from the Taipusi area have $\mathrm{Ta} / \mathrm{Yb}$ values ranging from 0.15 to 1.47, 

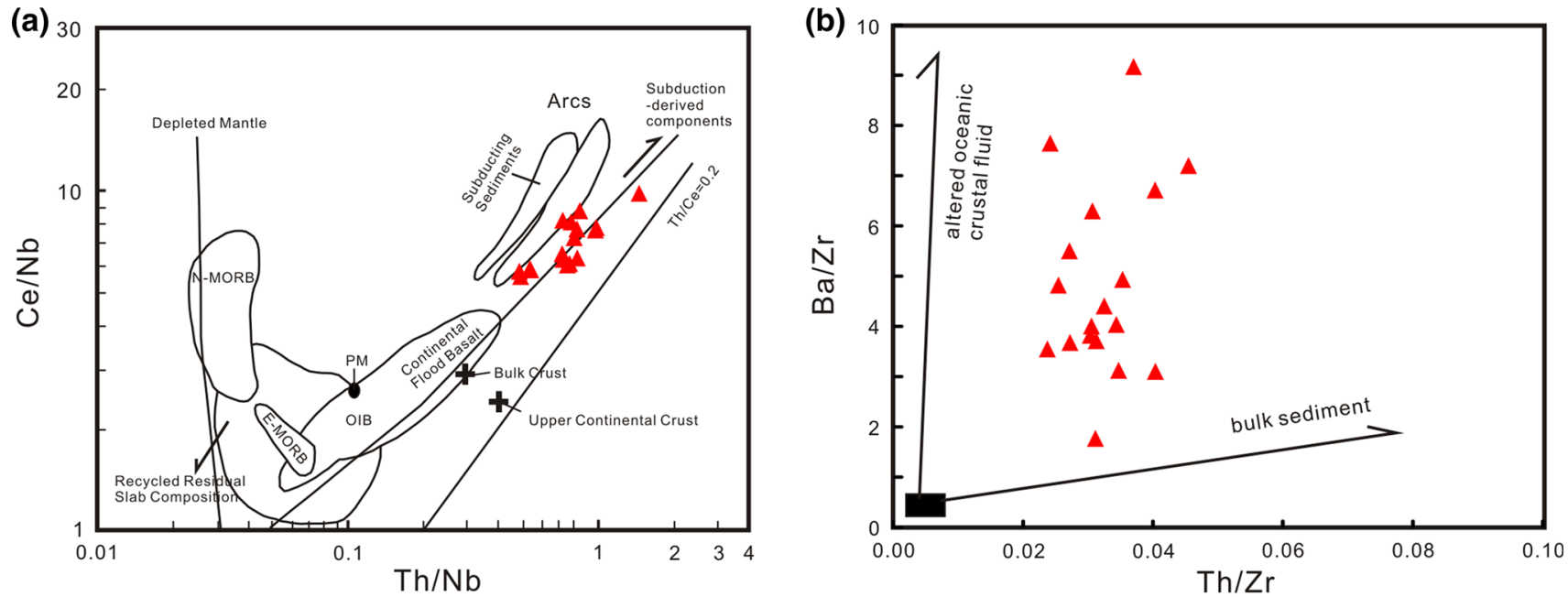

(c)

(d)
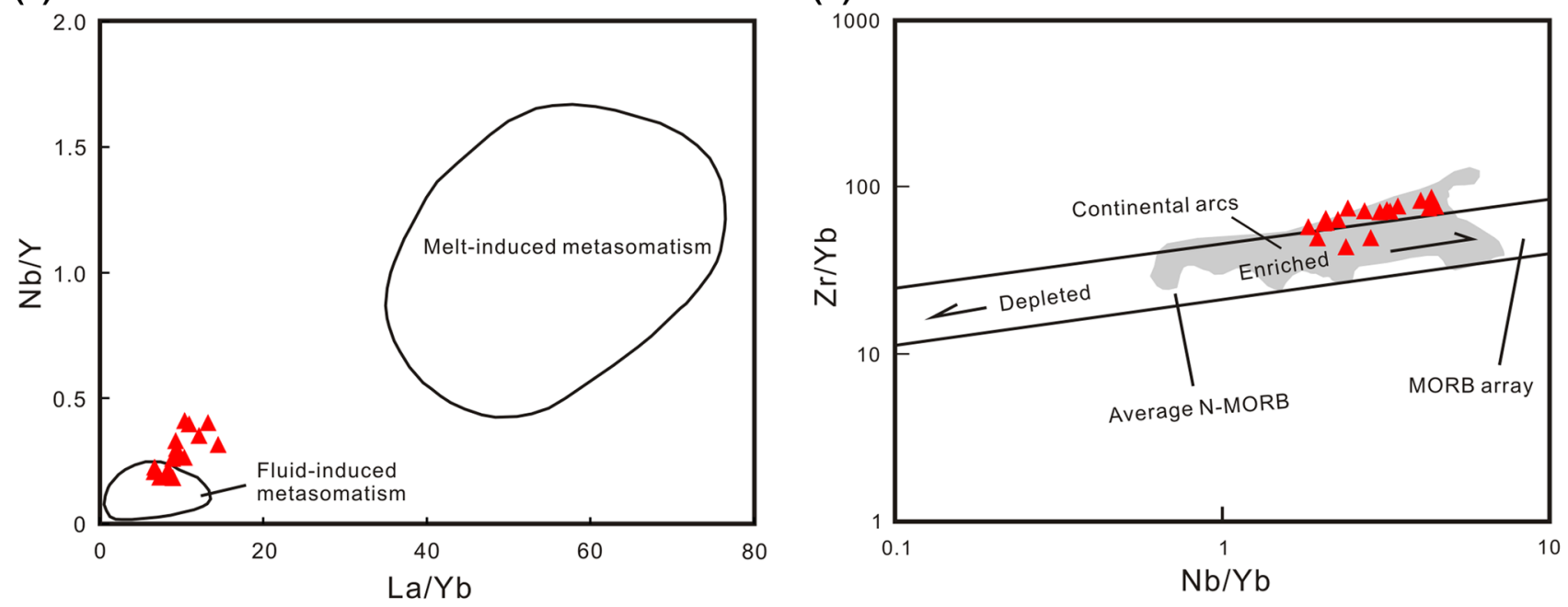

(e)

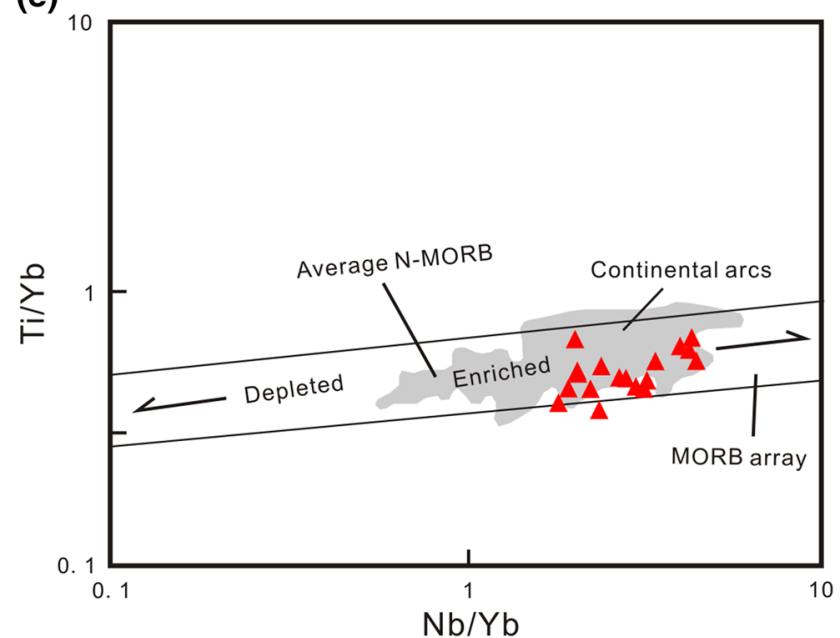

(f)

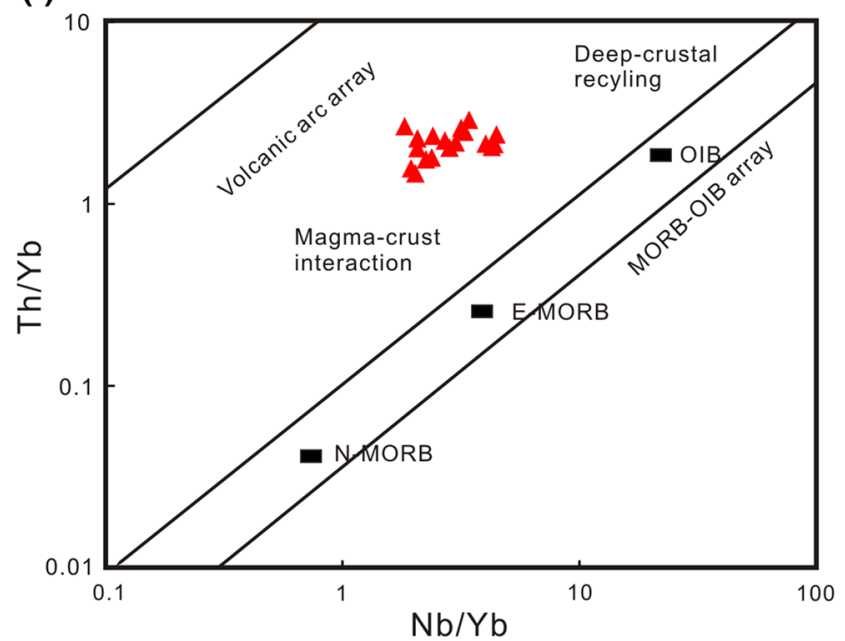

Figure 11. Discrimination diagrams of magma genesis and evolutionary process for the mafic rocks from the Taipusi area. (a) $\mathrm{Th} / \mathrm{Nb}$ vs. Ce/Nb diagram (after Song et al. 2004); (b) Th/Zr vs. Ba/Zr diagram (after Hoffer et al. 2008); (c) La/Yb vs. $\mathrm{Nb} / \mathrm{Y}$ diagram (after Ishizuka et al. 2003); (d) Nb/Yb vs. Zr/Yb diagram; (e) Nb/Yb vs. Ti/Yb diagram; (f) Nb/Yb vs. Th/Yb diagram (d), (e), and (f) after Pearce and Peate (1995). 

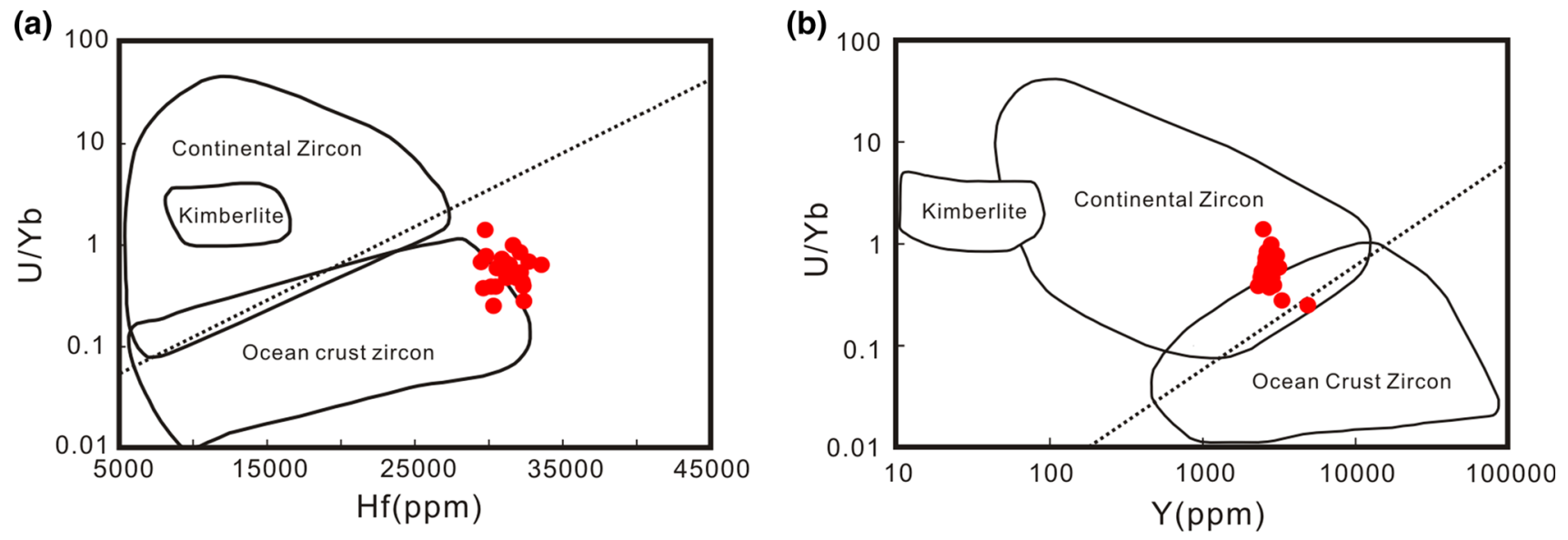

Figure 12. Discrimination diagrams of zircon crystallization environment for the mafic rocks from the Taipusi area. (a) $\mathrm{U} / \mathrm{Yb}$ vs. Hf diagram and (b) U/Yb vs. Y diagram (after Grimes et al. 2009).
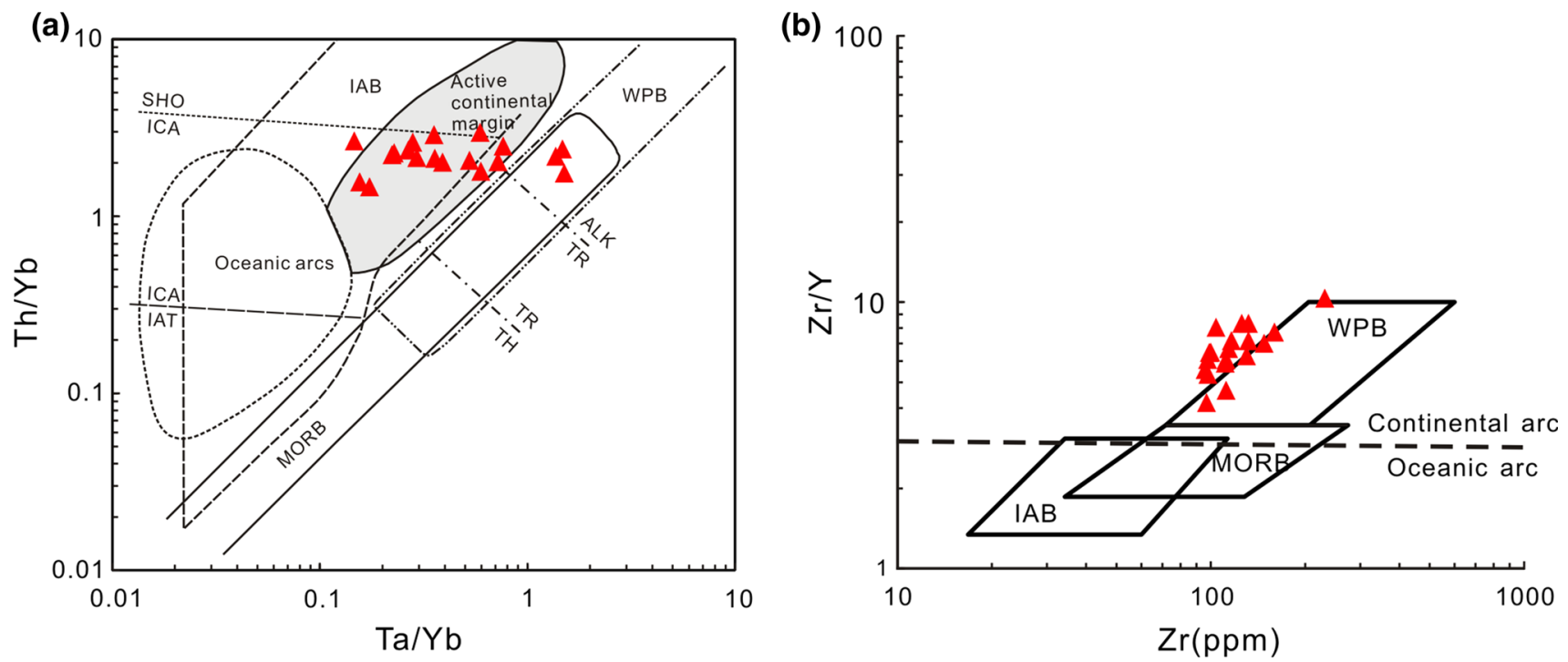

Figure 13. Discrimination diagrams of tectonic settings for the mafic rocks from the Taipusi area. (a) Ta/Yb vs. Th/Yb diagram (after Pearce 1982) and (b) Zr vs. Zr/Y diagram (after Pearce and Norry 1979 and Pearce 1983) IAB: Island arc basalt; IAT: Island arc tholeiite; ICA: Island calc-alkaline; SHO: Shoshonite; WPB: Within plate basalt; MORB: Mid-ocean ridge basalt; TH: Tholeiitic basalt; TR: Transitional basalt; ALK: Alkalic basalt.

which suggests a continental type arc environment (figure 13a). A more effective discrimination diagram for this purpose is the $\mathrm{Zr} / \mathrm{Y}$ vs. $\mathrm{Zr}$ diagram of Pearce (1983) presented in figure 13(b). The mafic rocks plot in the continental margin field, which essentially favors a continental arc origin.

There is additional evidence from elemental geochemistry pointing to a continental arc origin. The enrichment of LREE and inclined-LREE with flatHREE patterns are comparable with features of continental margin volcanic arc basalt, which are distinct from the normal mid-ocean ridge basalt and oceanic island basalt. Some elemental anomalies (such as $\mathrm{K}^{*}, \mathrm{Nb}^{*}$ and $\mathrm{Sr}^{*}$ ) can be used to determine tectonic setting and related evolutionary processes of magma (Xia et al. 2007). Basalts with $\mathrm{K}^{*}$ values higher than 1 could have originated from the island arc region and have close relationship with subduction (Nakamura et al. 1985). Mafic magmas contaminated by crustal materials or granitic rocks would have $\mathrm{Nb}^{*}$ values lower than 1. Sr* values $<1$ may be deemed as results of fractional crystallization of plagioclase or metasomatic alteration of fluids (Pin et al. 1988). For the mafic rocks in the Taipusi area, samples have values of $\mathrm{K}^{*}>1, \mathrm{Nb}^{*}<1$ and $\mathrm{Sr}^{*}>1$ (table 1), indicating that the magma was derived from the mantle beneath a continental island arc that was strongly affected by subduction, then contaminated by crustal or 
granitic materials with some degree of fractional crystallization.

The northern margin of NCC was strongly influenced by subduction of the Paleo-Asian ocean during the early Paleozoic to Triassic. The ca. 437 Ma mafic rocks in the Taipusi area reported in this study indicate that the middle part of the northern margin of NCC experienced subduction. These mafic rocks were formed under a subduction setting associated with enriched mantle wedge metasomatized by fluids from the subduction zone. The variable compositions of major and trace elements might be a reflection of a heterogeneous source composition, probably related to a subduction-modified sublithospheric mantle (Yang et al. 2014). This subduction process might have enriched the subcontinental mantle lithosphere.

In summary, the mafic rocks in the Taipusi area provide evidence of formation in a subduction environment. The mafic rocks in the Taipusi area inherited the features of continental arc rocks, and the mantle source was probably metasomatized by slab fluids with minor melts derived from either subducted oceanic slabs or pelagic sediments.

\subsection{Implications for tectonic evolution of $B A B$}

After the eastern landmass collided with the western landmass to form a single continental plate at $\sim 1.85 \mathrm{Ga}$, the NCC experienced a long period of steady tectonic evolution with a passive continental margin until the Early Cambrian (Wilde et al. 2002; Zhai and Santosh 2011). Afterward, the Early Paleozoic southward subduction of the Paleo-Asian ocean changed the northern margin of NCC into active continental margin. Previous studies indicate that magmatic activity related to this subduction in BAB was sustained about $80 \mathrm{Ma}$ from the Cambrian ( $\sim 500 \mathrm{Ma})$ to the Middle-Late Silurian ( $\sim 20 \mathrm{Ma})$ and peaked at Late Ordovician (Wang et al. 2012). However, different tectonic evolution models are applied to explain the closure process of the PAO, which mainly involves the longterm continuous subduction and the north-south differential subduction. Based on different models, the late Paleozoic magmatic activity in BAB may be related to island arc subduction or collisional orogenic tectonic setting.

Previous studies on the magmatic rocks in adjacent areas may offer further understanding for the tectonic evolution of BAB. Located to the north of BAB, the Ondor Sum Subduction-Accretionary Complex Belt developed a set of complexes formed by the subduction zone, which is composed of the Ondor Sum group, Deyeqimiao plagioclase amphibolite, ultramafic rocks and oligoclase granite. It is a subduction remnant of the PAO plate and a product of island arc magmatism. The Ondor Sum group is divided into the lower Sanda and upper Halhada formation, and is a set of accretionary complexes consisting of oceanic crust and intra-oceanic arc with different ages and genesis. Jong et al. (2006) reported a phengite ${ }^{40} \mathrm{Ar}-{ }^{39} \mathrm{Ar}$ age of $\sim 450$ Ma for the mylonite from the Halhada formation at the northern Ulan Arc, which is interpreted as the result of high-pressure metamorphism during subduction. Furthermore, Jian et al. (2008) obtained an age of 479.6 \pm 2.4 Ma from metamorphic gabbro cutting through the greenschist in the Tulinkai area. Consequently, it is considered that the Ondor Sum formation may have formed between late Cambrian and middle Silurian. The Deyangmiao plagioclase amphibolite is also related to the Ondor Sum subduction zone, which is the oceanic island arc that is formed by asthenospheric convection after oceanic-oceanic collision. Recently, Wang et al. (2015) gave a new zircon $\mathrm{U}-\mathrm{Pb}$ age of $490.3 \pm 4.6 \mathrm{Ma}$ of amphibolite series in eastern Ondor Sum area. Moreover, Liu et al. (2003) found a set of adakite rocks including quartz diorite, trondhjemite, anorthosite and dacite in the Tulinkai area and considered them as the mark of the early Paleozoic magmatic rocks resulting from subduction in this area. Geochronological results show that the earliest rock emplaced was the quartz diorite $(\sim 467 \mathrm{Ma})$, followed by a high-grade metamorphism event and partial melting process. The dacite and trondhjemite intruded at $\sim 459$ and $\sim 451 \mathrm{Ma}$ respectively; and finally the anorthosite dike was formed at $\sim 429$ Ma. In contrast, the ages of quartz diorite, dacite and anorthosite given by Jian et al. (2008) are $453.7 \pm 3.1,457.9 \pm 2.6$ and $425.3 \pm 2.2 \mathrm{Ma}$, respectively, indicating that the Ondor Sum-Tulinkai oceanic crust experienced $\sim 30$ Ma subduction during the early Paleozoic period. According to chronological data, the SOB could have developed two subduction zones between 453 and 425 Ma. The northern zone may represent the subduction zone of the intra-oceanic arc, and the southern zone may represent the subduction zone of the BAB. This suggests that the southern subduction of the PAO along the BAB from the early Ordovician to the middle Silurian led to intense 
late Precambrian - early Cambrian

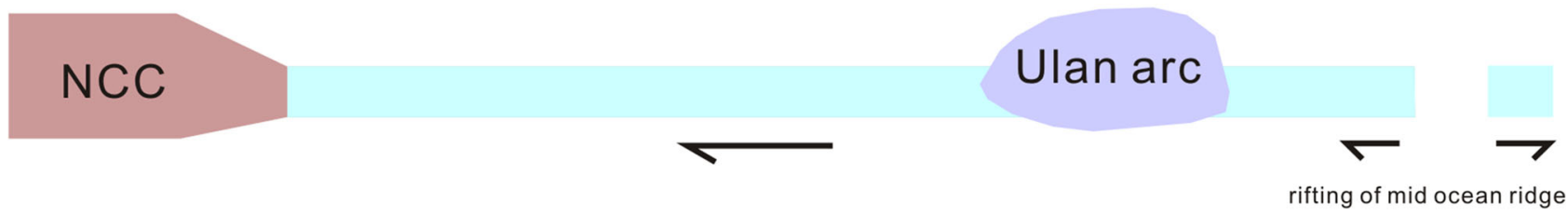

Cambrian - Silurian
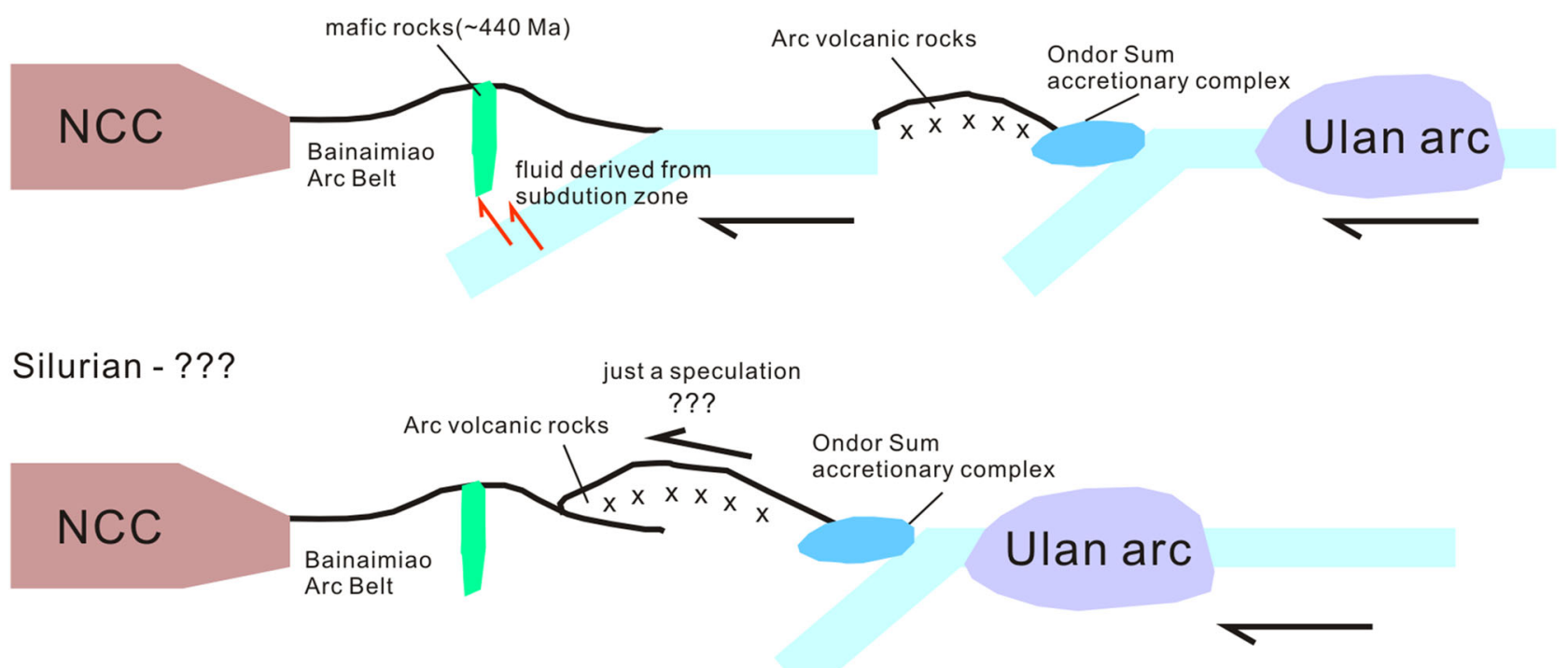

Figure 14. Cartoon-like profiles demonstrating the tectonic evolution of the Bainaimiao arc belt.

volcanic activity and the formation of widely distributed volcanic rocks in the northern margin of NCC.

The BAB has been recognized as an island arc by several authors (e.g., Tang and Yan 1993; Zhang et al. 2014). Correspondingly, the northern margin of NCC was considered as a passive continental margin on account of widely developed epicontinental sea sedimentation from the Cambrian to the middle Ordovician (Zhang et al. 2006). In addition, Zhang et al. (2014) proposed that the $\mathrm{BAB}$ is an ensialic island arc characterized by a different evolution history and basement compositions from the northern NCC. They also suggested that a South Bainaimiao Ocean existed between BAB and NCC during the Cambrian-Ordovician period. Long-term northward subduction brought about closure of the South Bainaimiao Ocean from the Early Cambrian to Middle Silurian (0.52$0.42 \mathrm{Ga}$ ) and final accretion of the Bainaimiao island arc to North China Craton during the Late Silurian to early Devonian by arc-continent collision. In comparison, the high initial strontium isotope ratio $\left({ }^{87} \mathrm{Sr} /{ }^{86} \mathrm{Sr}_{i}=0.7146\right)$ of granites (Shao $1989)$ and the $\varepsilon \mathrm{Nd}$ value of $2.4 \pm 1.7$ of granodiorite (Nie and Bjørlykke 1999) imply that the BAB formed by magma mixing between mantle-derived components and crustal rocks in an active continental Cordilleran-type margin rather than in an island arc (Xiao et al. 2003). Moreover, according to detailed geochronology and geochemistry of Bainaimiao metamorphic volcanic rocks, Liu et al. (2014) believed that the original magma of these rocks may have been derived from enriched mantle wedge and metasomatized by fluid during subduction and hybridized by continental crust materials, with active continental margin features.

Within the middle part of BAB, these mafic dikes from the Taipusi area have similar geochemical features with the Bainaimiao metavolcanic rocks, implying a similar source region and tectonic setting. Additionally, mafic dikes in the Taipusi area are dated at $\sim 440 \mathrm{Ma}$, which is also consistent with the peak magmatic activity of Bainaimiao Arc Belt during the Late Ordovician. The geochemical features of these Taipusi area mafic dikes suggest 
the tectonic environment of $\mathrm{BAB}$ to be a continental arc rather than an island arc. Hence, we conclude that the middle section of Bainaimiao Arc Belt once underwent intensive continental accretion caused by southward subduction of the Paleo-Asian ocean during the Early Paleozoic.

Consequently, the early Paleozoic tectonic evolution of the northern margin of NCC can be summarized as follows (figure 14): During the period from the late Precambrian to early Cambrian, the mid-ocean ridge of PAO gradually expanded and formed the Ondor Sum serpentinite that later migrated from the north to the south with the oceanic plate. Meanwhile, the Bainaimiao area continued to suffer from compression and stress accumulation. From Cambrian to Silurian, oceanocean subduction occurred on the south side of the Ondor Sum serpentinite, which resulted in an accretionary complex and arc volcanic rocks. At the same time, the northern margin of NCC was converted into an active continental margin, and the oceanic crust subducted under the continental crust. The metasomatism from subduction resulted in the formation of the mafic rocks in the Taipusi area.

\section{Conclusion}

- Zircon LA-ICP-MS U-Pb concordant ages of the mafic rocks in the Taipusi area are 437-442 $\mathrm{Ma}$, consistent with the peak magmatism at the Bainaimiao Arc Belt. This indicates that formation of these mafic rocks is associated with the Paleo-Asian Ocean southward subduction during Early Paleozoic.

- The magma of the mafic rocks originated from an altered enriched mantle that was probably metasomatized by subducting slab fluids, and underwent notable fractional crystallization and crustal contamination during their ascent through the lithosphere under an active continental arc setting.

- The middle section of Bainaimaio Arc Belt is a continental arc rather than an island arc during the early Silurian. No island arcs were generated and accreted to the northern North China Craton during late Devonian to early Silurian.

\section{Acknowledgements}

This work was co-financed by the Fundamental Research Funds for the Central Universities, China
University of Geosciences (Wuhan) (Grant No. CUG150612) and the National Natural Science Foundation of China (Grant No. 41502067). The authors thank anonymous reviewers for their detailed and valuable comments that greatly improved the manuscript.

\section{References}

Andersen T 2002 Correction of common lead in U-Pb analyses that do not report ${ }^{204} \mathrm{~Pb}$; Chem. Geol. 192(1-2) 59-79.

Ballard J R, Palin J M and Campbell I H 2002 Relative oxidation states of magmas inferred from Ce (IV)/Ce (III) in zircon: Application to porphyry copper deposits of northern Chile; Contrib. Mineral. Petrol. 144(3) 347-364.

Bau M 1996 Controls on the fractionation of isovalent trace elements in magmatic and aqueous systems: Evidence from Y/Ho, Zr/Hf, and lanthanide tetrad effect; Contrib. Mineral. Petrol. 123(3) 323-333.

Belousova E A, Griffin W L, O'Reilly S Y and Fisher N I 2002 Igneous zircon: Trace element composition as an indicator of source rock type; Contrib. Mineral. Petrol. 143(5) 602-622.

Belousova E A, Griffin W L and O'Reilly S Y 2006 Zircon crystal morphology, trace element signatures and $\mathrm{Hf}$ isotope composition as a tool for petrogenetic modelling: Examples from eastern Australian granitoids; $J$. Petrol. 47(2) 329-353.

Chen B, Jahn B M, Wilde S and Xu B 2000 Two contrasting Paleozoic magmatic belts in northern Inner Mongolia, China: Petrogenesis and tectonic implications; Tectonophys. 328(1) 157-182.

Chen B, Jahn B M and Tian W 2009 Evolution of the Solonker suture zone: Constraints from zircon $\mathrm{U}-\mathrm{Pb}$ ages, $\mathrm{Hf}$ isotopic ratios and whole-rock $\mathrm{Nd}-\mathrm{Sr}$ isotope compositions of subduction- and collision-related magmas and forearc sediments; J. Asian Earth Sci. 34(3) 245-257.

Claiborne L L, Miller C F and Wooden J L 2010 Trace element composition of igneous zircon: A thermal and compositional record of the accumulation and evolution of a large silicic batholith, Spirit Mountain, Nevada; Contrib. Mineral. Petrol. 160(4) 511-531.

Cope T, Ritts B, Darby B, Fildani A and Graham S 2005 Late Paleozoic sedimentation on the northern margin of the North China block: Implications for regional tectonics and climate change; Int. Geol. Rev. 47(3) 270-296.

Donnelly K E, Goldstein S L, Langmuir C H and Spiegelman M 2004 Origin of enriched ocean ridge basalts and implications for mantle dynamics; Earth Planet. Sci. Lett. 226(3-4) 347-366.

Eiler J M, Grawford A, Elliott T, Farley K A, Valley J W and Stolper E M 2000 Oxygen isotope geochemistry of oceanic arc lavas; J. Petrol. 41(2) 229-256.

Feng X X, Yao S Z, Wang J S, Wei J L, Li G Y, Wang J Y and Feng X B 2014 LA-MC-ICP-MS zircon U-Pb dating of the pluton in the Bainaimiao $\mathrm{Cu}-\mathrm{Mo}$ deposit of Inner Mongolia and its geological significance; Geol. Explor. 18(2) 179-197 (in Chinese with English abstract). 
Grimes C B, John B E, Kelemen P B, Mazdab F, Wooden J L, Cheadle M J, Hanghoj K and Schwartz J J 2007 The trace element chemistry of zircons from oceanic crust: A method for distinguishing detrital zircon provenance; Geology 35(7) 643-646.

Grimes C B, John B E, Cheadle M J, Mazdab F K, Wooden J L, Swapp S and Schwartz J J 2009 On the occurrence, trace element geochemistry, and crystallization history of zircon from in situ ocean lithosphere; Contrib. Mineral. Petrol. 158(6) 757-783.

Grove T L, Elkins-Tanton L T, Parman S W, Chatterjee N, Müntener O and Gaetani G A 2003 Fractional crystallization and mantle melting controls on calc-alkaline differentiation trends; Contrib. Mineral. Petrol. 145(5) $515-533$.

Han Y G, Zhang S H, Pirajno F, Zhou X W, Zhao G C, Qü W J, Liu S H, Zhang J M, Liang H B and Yang K 2013 U$\mathrm{Pb}$ and $\mathrm{Re}-\mathrm{Os}$ isotopic systematics and zircon $\mathrm{Ce}^{4+} / \mathrm{Ce}^{3+}$ ratios in the Shiyaogou Mo deposit in eastern Qinling, central China: Insights into the oxidation state of granitoids and Mo (Au) mineralization; Ore Geol. Rev. 55(15) 29 47.

Hey M H 1982 The determination of ferrous and ferric iron in rocks and minerals and a note on sulphosalicylic acid as a reagent for Fe and Ti; Mineral. Mag. 46(341) 111-118.

Hoffer G, Eissen J P, Beate B, Bourdon E, Fornari M and Cotton J 2008 Geochemical and petrological constraints on rear-arc magma genesis processes in Ecuador: The Puyo cones and Mera lavas volcanic formations; J. Volcanol. Geotherm. Res. 176(1) 107-118.

Hofmann A W 1988 Chemical differentiation of the Earth: The relationship between mantle, continental crust, and oceanic crust; Earth Planet. Sci. Lett. 90(3) 297-314.

Hoskin P W O, Kinny P D, Wyborn D and Chappell B W 2000 Identifying accessory mineral saturation during differentiation in granitoid magmas: An integrated approach; J. Petrol. 41(9) 1365-1396.

Hoskin P W O and Schaltegger U 2003 The composition of zircon and igneous and metamorphic petrogenesis; Rev. Mineral. Geochem. 53(1) 27-62.

Hoskin P W O 2005 Trace-element composition of hydrothermal zircon and the alteration of Hadean zircon from the Jack Hills, Australia; Geochim. Cosmochim. Acta 69(3) $637-648$.

Irvine T N and Baragar W R A 1971 A guide to the chemical classification of the common volcanic rocks; Can. J. Earth Sci. 8(5) 523-548.

Ishizuka O, Taylor R N, Milton J A and Nesbitt R W 2003 Fluid-mantle interaction in an intra-oceanic arc: Constraints from high-precision $\mathrm{Pb}$ isotopes; Earth Planet. Sci. Lett. 211(3-4) 221-236.

Jahn B M 2004 The Central Asian Orogenic Belt and growth of the continental crust in the Phanerozoic; Geol. Soc. Lond. Spec. Publ. 226(1) 73-100.

Jesus A P, Mateus A, Munhá J M and Tassinari C 2014 Internal architecture and $\mathrm{Fe}-\mathrm{Ti}-\mathrm{V}$ oxide ore genesis in a Variscan synorogenic layered mafic intrusion the Beja Layered Gabbroic Sequence (Portugal); Lithos 190-191(3) $111-136$

Jian P, Liu D, Kröner A, Windley B F, Shi Y, Zhang F, Shi G, Miao L, Zhang W, Zhang L and Ren J 2008 Time scale of an early to mid-Paleozoic orogenic cycle of the long-lived Central Asian Orogenic Belt, Inner Mongolia of China: Implications for continental growth; Lithos 101(3-4) 233-259.

Jian P, Liu D and Kröner A 2010 Evolution of a Permian intraoceanic arc-trench system in the Solonker suture zone, Central Asian Orogenic Belt, China and Mongolia; Lithos 118(1-2) 169-190.

Jong K D, Xiao W, Windley B F, Masago H and Lo C H 2006 Ordovician ${ }^{40} \mathrm{Ar} /{ }^{39} \mathrm{Ar}$ phengite ages from the blueschistfacies Ondor Sum subduction-accretion complex (Inner Mongolia) and implications for the early Paleozoic history of continental blocks in China and adjacent areas; Am. J. Sci. 106(10) 799-845.

Khain E V, Bibikova E V, Salnikova E B, Kröner A, Gibsher A S, Didenko A N, Degtyarev K E and Fedotova A A 2003 The Palaeo-Asian Ocean in the Neoproterozoic and early Palaeozoic: New geochronologic data and palaeotectonic reconstructions; Precamb. Res. 122(1) 329-358.

Kieffer B, Arndt N, Lapierre H, Bastien F, Bosch D, Pecher A, Yirgu G, Ayalew D, Weis D, Jerram D A, Keller F and Meugniot C 2004 Flood and shield basalts from Ethiopia: Magmas from the African Superswell; J. Petrol. 45(4) 793-834.

Li H, Watanabe K, Xi X S and Yonezu K 2013 Geochemistry of volcanic rocks at Zhaokalong iron-copper polymetallic ore deposit, Qinghai Province, China: Implications for the tectonic background; Proc. Earth Planet. Sci. 6 58-63.

Li H, Watanabe K and Yonezu K 2014 Zircon morphology, geochronology and trace element geochemistry of the granites from the Huangshaping polymetallic deposit, South China: Implications for the magmatic evolution and mineralization processes; Ore Geol. Rev. 60 14-35.

Li H, Xi X S, Sun H S, Kong H, Wu Q H, Wu C M and GaboRatio J A S 2016 Geochemistry of the Batang Group in the Zhaokalong area, Yushu, Qinghai: Implications for the Late Triassic tectonism in the northern Sanjiang region, China; Acta Geol. Sin.-Engl. Ed. 90(2) 704-721.

Li H, Sun H S, Wu J H, Evans N J, Xi X S, Peng N L, Cao J Y and Gabo-Ratio J A S 2017 Re-Os and U-Pb geochronology of the Shazigou Mo polymetallic ore field, Inner Mongolia: Implications for Permian-Triassic mineralization at the northern margin of the North China Craton; Ore Geol. Rev. 83 287-299.

Li J F, Zhang Z C and Han B F 2010 Ar-Ar and zircon SHRIMP geochronology of hornblendite and diorite in northern Darhan Muminggan Joint Banner, Inner Mongolia, and its geological significance; Acta Petrol. Mineral. 29(6) 732-740.

Li Y L, Zhou H W, Xiao W J, Zhong Z Q and Yin S P 2012a Superposition of Paleo-Asian and West-Pacific tectonic domains in the eastern section of the Solonker Suture Zone: Insights from petrology, geochemistry and geochronology of deformed diorite in Xar Moron Fault Zone, Inner Mongolia; J. China Univ. Geosci. 37(3) 433450.

Li W, Zhong R, Xu C, Song B and Qu W 2012b U-Pb and Re-Os geochronology of the Bainaimiao $\mathrm{Cu}-\mathrm{Mo}-$ $\mathrm{Au}$ deposit, on the northern margin of the North China Craton, Central Asia Orogenic Belt: Implications for ore genesis and geodynamic setting; Ore Geol. Rev. 48139 150. 
Li W B, Hu C S, Zhong R C and Zhu F 2015 U-Pb, ${ }^{39} \mathrm{Ar} /{ }^{40} \mathrm{Ar}$ geochronology of the metamorphosed volcanic rocks of the Bainaimiao Group in central Inner Mongolia and its implications for ore genesis and geodynamic setting; J. Asian Earth Sci. 97 251-259.

Linnen R L and Keppler H 2002 Melt composition control of $\mathrm{Zr} / \mathrm{Hf}$ fractionation in magmatic processes; Geochim. Cosmochim. Acta 66(18) 3293-3301.

Liu C F, Liu W C, Wang H P, Zhou Z, Zhang H and Tang Y 2014 Geochronology and Geochemistry of the Bainaimiao Metavolcanic Rocks in the Northern Margin of North China Craton; Acta Geol. Sin. 88(7) 1273-1287 (in Chinese with English abstract).

Liu D, Jian P, Zhang Q, Zhang F, Shi Y, Shi G, Zhang N and Tao H 2003 SHRIMP dating of adakites in the Tulingkai Ophiolite, Inner Mongolia: Evidence for the early Paleozoic subduction; Acta Geol. 77(3) 317-327 (in Chinese with English abstract).

Liu Y S, Hu Z C, Gao S, Günther D, Xu J, Gao C and Chen H 2008 In situ analysis of major and trace elements of anhydrous minerals by LA-ICP-MS without applying an internal standard; Chem. Geol. 257(1-2) 34-43.

Liu Y S, Gao S, Hu Z C, Gao C G, Zong K Q and Wang D 2010 Continental and oceanic crust recyclinginduced melt-peridotite interactions in the Trans-North China Orogen: U-Pb dating, Hf isotopes and trace elements in zircons of mantle xenoliths; J. Petrol. 51(1-2) $537-571$.

Miao L C, Fan W M, Liu D Y, Zhang F, Shi Y and Guo F 2008 Geochronology and geochemistry of the Hegenshan ophiolitic complex: Implications for late stage tectonic evolution of the Inner Mongolia-Daxinganling Orogenic Belt; China J. Asian Earth Sci. 32(5-6) 348-370.

Nakamura E, Campbell I H and Sun S S 1985 The influence of subduction processes on the geochemistry of Japanese alkaline basalts; Nature 316 55-58.

Nie F and Bjørlykke A $1999 \mathrm{Nd}$ and Sr isotope constraints on the age and origin of Proterozoic metamafic volcanic rocks in the Bainaimiao-Wenduermiao district, south-central Inner Mongolia, China; Cont. Dyn. 4(1) $1-14$.

O'Hara M J, Fry N and Prichard H M 2001 Minor phases as carriers of trace elements in non-modal crystal-liquid separation processes II: Illustrations and bearing on behavior of REE, U, Th and the PGE in igneous processes; $J$. Petrol. 42(10) 1887-1910.

Pearce J A and Norry M J 1979 Petrogenetic implications of $\mathrm{Ti}, \mathrm{Zr}, \mathrm{Y}$, and $\mathrm{Nb}$ variations in volcanic rocks; Contrib. Mineral. Petrol. 69(1) 33-47.

Pearce J A 1982 Trace element characteristics of lavas from destructive plate boundaries; Andesites 4(1) 528-548.

Pearce J A 1983 Role of the sub-continental lithosphere in magma genesis at active continental margins; J. Electrochem. Soc. 147(6) 2162-2173.

Pearce J A and Peate D W 1995 Tectonic implications of the composition of volcanic ARC magmas; Annu. Rev. Earth Planet. Sci. 23(23) 251-285.

Pearce J A and Stern R J 2006 Origin of Backarc Basin Magmas: Trace element and isotope perspectives; $A m$. Geophys. Union 166 63-86.

Peccerillo R and Taylor S R 1976 Geochemistry of Eocene calc-alkaline volcanic rocks from the Kastamonu area, northern Turkey; Contrib. Mineral. Petrol. 58(1) $63-81$.

Pin C, Majerowicz A and Wojciechowska I 1988 Upper Paleozoic oceanic crust in the Polish Sudetes: Nd-Sr isotope and trace element evidence; Lithos 21(3) 195-209.

Santosh M 2010 Assembling North China Craton within the Columbia supercontinent: The role of double-sided subduction; Precamb. Res. 178(1-4) 149-167.

Sengör A M C, Natal'in B A and Burtman V S 1993 Evolution of the Altaid tectonic collage and Paleozoic crustal growth in Eurasia; Nature 364 299-307.

Shao J A 1989 Continental crust accretion and tectonomagmatic activity at the northern margin of the Sino-Korean plate; J. Southeast Asian Earth Sci. 3(1-4) 57-62.

Song X Y, Zhou M F, Cao Z M and Robinson P T 2004 Late Permian rifting of the South China Craton caused by the Emeishan mantle plume; J. Geol. Soc. 161(5) 773-781.

Stampfli G M and Borel G D 2002 A plate tectonic model for the Paleozoic and Mesozoic constrained by dynamic plate boundaries and restored synthetic oceanic isochrones; Earth Planet. Sci. Lett. 196(1-2) 17-33.

Sun S S and McDonough W F 1989 Chemical and isotopic systematics of oceanic basalts: Implication for mantle composition and processes; Geol. Soc. London Spec. Publ. 42 313-345.

Tang K D and Yan Z Y 1993 Regional metamorphism and tectonic evolution of the Inner Mongolian suture zone; $J$. Metamorph. Geol. 11(4) 511-522.

Trail D, Watson E B and Tailby N D 2011 The oxidation state of Hadean magmas and implications for early Earth's atmosphere; Nature 480 79-83.

Wang X, Xu Z Y, Liu Z H, Wang W F, Wei L Y, Li F, Liu M N, Chang L, Li G Y and Liu X 2015 Geochronological, geochemical characteristics and geological significance of deyanqimiao amphibolite series in Inner Mongolia; $J$. Earth Sci. Environ. 37(02) 1-10 (in Chinese with English abstract).

Wang F, Xu W L, Meng E, Cao H H and Gao F H 2012 Early Paleozoic Amalgamation of the Songnen-Zhangguangcai Range and Jiamusi Massifs in the eastern segment of the Central Asian Orogenic Belt: Geochronological and geochemical evidence from granitoids and rhyolites; J. Asian Earth Sci. 49(3) 234-248.

Weaver B L 1991 The origin of ocean island basalt endmember compositions: Trace element and isotopic constraints; Earth Planet. Sci. Lett. 104(2-4) 381-397.

Wilde S A, Zhao G C and Sun M 2002 Development of the North China Craton during the Late Archaean and its amalgamation along a major $18 \mathrm{Ga}$ collision zone including speculations on its position within a global Paleoproterozoic Supercontinent; Gondwana Res. 5(1) 85-94.

Winchester J A and Floyd P A 1977 Geochemical discrimination of different magma series and their differentiation products using immobile elements; Chem. Geol. 20(4) 325-343.

Windley B F, Alexeiev D, Xiao W J, Kroner A and Badarch G 2006 Tectonic models for accretion of the Central Asian Orogenic Belt; J. Geol. Soc. 164(12) 31-47.

Xia L Q, Xia Z C, Xu X Y, Li X M and Ma Z P 2007 The discrimination between continental basalt and island arc basalt based on geochemical method; Acta Petrol. Mineral. 26 77-89 (in Chinese with English abstract). 
Xiao W J, Windley B F, Hao J and Zhai M G 2003 Accretion leading to collision and the Permian Solonker suture, Inner Mongolia, China: Termination of the central Asian orogenic belt; Tectonics 22(6) 8-1.

Xiao W J, Windley B F, Badarch G, Sun S, Li J, Qin K and Wang Z 2004 Palaeozoic accretionary and convergent tectonics of the southern Altaids: Implications for the growth of Central Asia; J. Geol. Soc. 161(3) 339-342.

Xiao W J, Windley B F, Huang B C, Han C M, Yuan C, Chen H L, Sun M, Sun S and Li J L 2009 EndPermian to mid-Triassic termination of the accretionary processes of the southern Altaids: Implications for the geodynamic evolution, Phanerozoic continental growth, and metallogeny of Central Asia; Int. J. Earth Sci. 98(6) 1189-1287.

Xu B, Charvet J, Chen Y, Zhao P and Shi G 2013 Middle Paleozoic convergent orogenic belts in western Inner Mongolia (China): Framework, kinematics, geochronology and implications for tectonic evolution of the Central Asian Orogenic Belt; Gondwana Res. 23(4) 1342-1364.

$\mathrm{Xu} \mathrm{M}$ J, Li C, Xu W, Xie C M, Hu P Y and Wang M 2014 Petrology, geochemistry and geochronology of gabbros from the Zhongcang ophiolitic mélange, central Tibet: Implications for an intra-oceanic subduction zone within the Neo-Tethys Ocean; J. Earth Sci. 25(2) 224-240.

Yang Q Y, Santosh M and Dong G C 2014 Late Palaeoproterozoic post-collisional magmatism in the North China Craton: Geochemistry, zircon U-Pb geochronology, and Hf isotope of the pyroxenite-gabbro-diorite suite from Xinghe, Inner Mongolia; Int. Geol. Rev. 56(8) 959-984.

Yuan H L, Gao S, Dai M N, Zong C L, Günther D, Fontaine G H, Liu X M and Diwu C R 2008 Simultaneous determinations of $\mathrm{U}-\mathrm{Pb}$ age, $\mathrm{Hf}$ isotopes and trace element compositions of zircon by excimer laser-ablation quadrupole and multiple-collector ICPMS; Chem. Geol. 247(1-2) $100-118$.

Zhai M G and Santosh M 2011 The early Precambrian odyssey of the North China Craton: A synoptic overview; Gondwana Res. 20(1) 6-25.

Zhai M, Bo H U, Peng P and Zhao T 2014 MesoNeoproterozoic magmatic events and multi-stage rifting in the NCC; Earth Sci. Front. 21 100-119 (in Chinese with English abstract).

Corresponding editor: R K Srivastava
Zhang S H, Zhao Y and Song B 2006 Hornblende thermobarometry of the Carboniferous granitoids from the Inner Mongolia paleo-uplift: Implications for the geotectonic evolution of the northern margin of North China block; Mineral. Petrol. 87(1) 123-141.

Zhang S H, Zhao Y, Ye H, Liu J M and Hu Z C 2014 Origin and evolution of the Bainaimiao arc belt: Implications for crustal growth in the southern Central Asian orogenic belt; Geol. Soc. Am. Bull 126(9-10) 1275-1300.

Zhang W and Jian P 2008 SHRIMP dating of early Paleozoic granites from North Damaoqi, Inner Mongolia; Acta Geol. Sin. 82(6) 779-787 (in Chinese with English abstract).

Zhang W, Jian P, Kröner A and Shi Y R 2013 Magmatic and metamorphic development of an early to mid-Paleozoic continental margin arc in the southernmost Central Asian Orogenic Belt, Inner Mongolia, China; J. Asian Earth Sci. 72(4) 63-74.

Zhang X H, Zhang H F, Jiang N, Zhai M G and Zhang Y B 2010 Early Devonian alkaline intrusive complex from the northern North China craton: A petrological monitor of post-collisional tectonics; J. Geol. Soc. 167(4) 717-730.

Zhao G C, Wilde S A, Cawood P A and Sun M 2001 Archean blocks and their boundaries in the North China Craton: Lithological, geochemical, structural and $\mathrm{P}-\mathrm{T}$ path constraints and tectonic evolution; Precamb. Res. 107(1-2) $45-73$.

Zhao G C, Wilds S A, Guo J H, Cawood P A, Sun M and Li X 2010 Single zircon grains record two Paleoproterozoic collisional events in North China Craton; Precamb. Res. 177(3) 266-276.

Zhao G C and Zhai M G 2013 Lithotectonic elements of Precambrian basement in the North China Craton: Review and tectonic implications; Gondwana Res. 23(4) 12071240 .

Zhao S, Xu W L, Wang W, Tang J and Zhang Y H 2014 Geochronology and geochemistry of Middle-Late Ordovician granites and gabbros in the Erguna region, NE China: Implications for the tectonic evolution of the Erguna Massif; J. Earth Sci. 25 841-853.

Zhou J L, Shao S, Luo Z H, Shao J B, Wu D T and Rasoamalala V 2015 Geochronology and geochemistry of Cryogenian gabbros from the Ambatondrazaka area, east-central Madagascar: Implications for MadagascarIndia correlation and Rodinia paleogeography; Precamb. Res. 256(8) 256-270. 